\title{
Highly flexible synthesis of indenylethylamines as ligand precursors for titanium complexes
}

\author{
Jan H. Ross, Stefan H. Rohjans, Marc Schmidtmann, and Sven Doye* \\ Institut für Chemie, Universität Oldenburg, Carl-von-Ossietzky-Strasse 9-11, \\ 26111 Oldenburg, Germany \\ E-mail: doye@uni-oldenburg.de
}

\section{Dedicated to Professor Jürgen Martens in honor of his outstanding contribution to synthetic organic chemistry}

DOI: http://dx.doi.org/10.3998/ark.5550190.p008.859

\begin{abstract}
Various indenylethylamines are synthesized for the first time by reductive amination of 2-(1Hinden-1-yl)acetaldehyde with commercially available primary amines. In addition, a new twostep synthesis of 2-(1H-inden-1-yl)acetaldehyde that uses inexpensive indene and 2-bromo-1,1diethoxyethane as starting materials is presented. Finally, a selected indenylethylamine is used as a ligand precursor for the synthesis of a corresponding indenylethylamido titanium complex. The latter result paves the way for applications of corresponding complexes as catalysts for important chemical reactions.
\end{abstract}

Keywords: Amines, hydroaminoalkylation, indene, reductive amination, titanium

\section{Introduction}

Transition metal complexes which are formed by coordination of ligands to metals are widely used as catalysts for a plethora of synthetically useful chemical transformations. However, in most cases, extensive optimization studies are necessary to finally develop an efficient and reliable new catalytic reaction. A common and powerful possibility to optimize transition metal catalysts is the variation of the ligands which are bound to the metal center and as a consequence, an ever-present demand for new ligand motifs exists in transition metal chemistry.

The titanium-catalyzed hydroaminoalkylation of alkenes (Scheme 1$)^{1-11}$ is a relatively new and promising method for a waste-free synthesis of industrially important amines. The reaction takes place by addition of the $\alpha-\mathrm{C}-\mathrm{H}$ bond of an amine across a $\mathrm{C}-\mathrm{C}$ double bond and gives access to $\alpha$-alkylated amines in a single step and with $100 \%$ atom efficiency. Among the various titanium-catalysts, bis $\left(\eta^{5}\right.$-indenyl)dimethyltitanium $\left(\operatorname{Ind}_{2} \mathrm{TiMe}_{2}\right)^{12}$ was found to be an excellent 
catalyst for the highly regioselective hydroaminoalkylation of 1 -alkenes with $N$-methylanilines (Scheme 1). ${ }^{5}$ In addition, the catalyst can be used for corresponding reactions of styrenes ${ }^{5}$ and 1,3-butadienes ${ }^{9}$ even though reduced regioselectivities are observed in these cases. On the other hand, dialkylamines and $\mathrm{N}$-alkylanilines bearing alkyl groups larger than a methyl group do not undergo successful hydroaminoalkylation reactions in the presence of $\operatorname{Ind}_{2} \mathrm{TiMe}_{2}$.

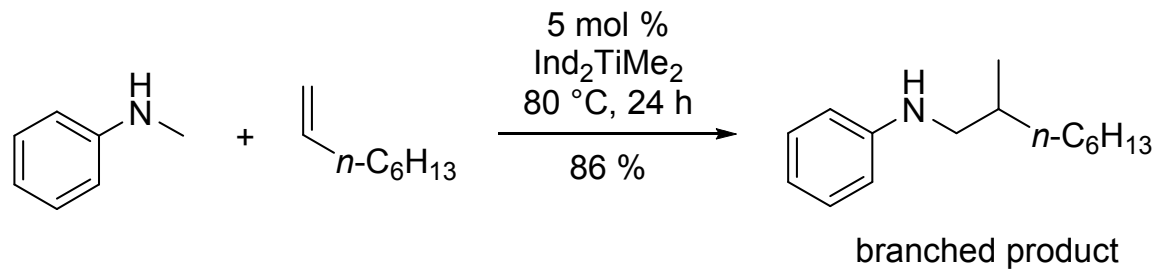

Scheme 1. $\operatorname{Ind}_{2} \mathrm{TiMe}_{2}$-catalyzed hydroaminoalkylation reaction of 1-octene with $N$-methylaniline. ${ }^{5}$

The reaction mechanism of the titanium-catalyzed hydroaminoalkylation of alkenes has already been studied in detail ${ }^{6}$ and it is generally accepted that titanaaziridines are the catalytically active species. These highly strained intermediates are formed under the reaction conditions from a catalyst precursor and the amine substrate. However, it is well established that in the presence of amines, bis $\left(\eta^{5}\right.$-cyclopentadienyl)titanium precursors $\left(\mathrm{Cp}_{2} \mathrm{TiL}_{n}\right)$ undergo an unexpected cyclopentadienide/amide ligand exchange reaction that results in the formation of mono $\left(\eta^{5}\right.$-cyclopentadienyl)titanium(amido) complexes $\left(\mathrm{Cp}(\mathrm{RNH}) \mathrm{TiL}_{\mathrm{n}}\right.$, Scheme 2$) .{ }^{13}$ In analogy, it can be assumed that the catalyst precursor $\operatorname{Ind}_{2} \mathrm{TiMe}_{2}$ used for hydroaminoalkylation reactions of alkenes undergoes a comparable ligand exchange reaction with the amine substrate and as a result, the expected catalytically active titanaaziridine formed from $\mathrm{Ind}_{2} \mathrm{TiMe}_{2}$ possesses only one indenyl ligand and an amido ligand (Scheme 2). However, these two ligands are expected to remain bonded to the titanium center during the entire catalytic cycle and as a consequence, they both determine the activity of the catalytic species.

A major drawback of the expected ligand exchange of one indenyl ligand against an amido ligand is the fact that the reactivity of the catalytically active titanaaziridine is directly influenced by the nature of the amine substrate. Consequently, the undesirable possibility exists that a certain class of amine substrates, e.g. aromatic amines, deliver catalytic species of high activity while the use of other classes of amines, e.g. alkylamines, results in poorly active catalysts. One approach to avoid this unwanted dependency of the activity of the catalytic species on the nature of the amine substrate is to use a catalyst precursor that contains a chelating ligand with a bridged amido indenyl ligand. Corresponding silyl-linked amido cyclopentadienyl or amido indenyl ligands have extensively been used for the synthesis of various so-called constrained geometry catalysts in recent years, ${ }^{14}$ but the notoriously labile Si-N-linkage encouraged us to focus on more stable catalyst precursors with chelating indenylethylamido ligands which are shown in Scheme 3 (general structure 1). In this context, it must also be noted that the potential 
new class of hydroaminoalkylation catalyst precursors of type 1 offers the additional possibility to fine-tune the catalyst by varying the substituent $\mathrm{R}$ bound to the nitrogen atom of the chelating ligand. From a retrosynthetic point of view, dimethyl titanium complexes of structure $\mathbf{1}$ should be easily accessible from the corresponding dichloro titanium complexes $\mathbf{2}$ and a nucleophilic methylation reagent, e.g. methyl lithium. Unfortunately, complexes of type $\mathbf{2}$ have not been described in the literature.

Bergman 2001: cyclopentadienide/amide ligand exchange ${ }^{13}$

$$
\mathrm{Cp}_{2} \mathrm{TiMe}_{2} \underset{-\mathrm{CpH}-2 \mathrm{CH}_{4}}{\stackrel{+2 \mathrm{RNH}_{2}+\mathrm{py}}{\longrightarrow}}
$$

Expected formation of a catalytically active hydroaminoalkylation catalyst

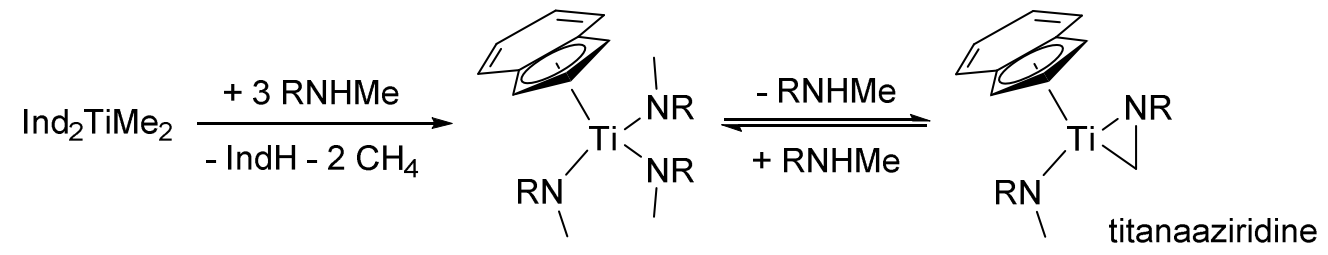

Scheme 2. Ligand exchange reactions of $\mathrm{Cp}_{2} \mathrm{TiMe}_{2}$ and $\mathrm{Ind}_{2} \mathrm{TiMe}_{2}$ in the presence of amines.

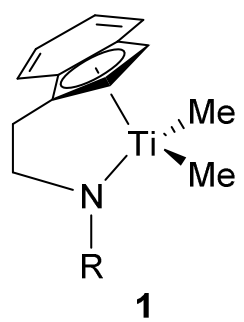

1

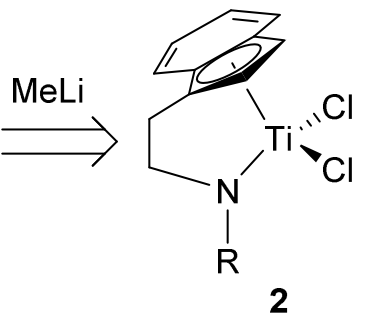

2

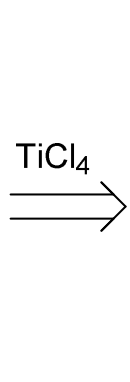

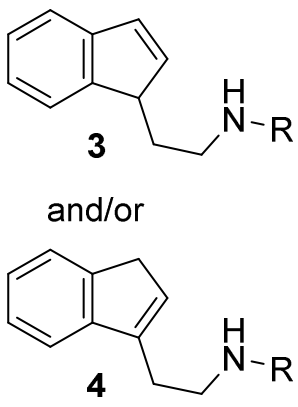

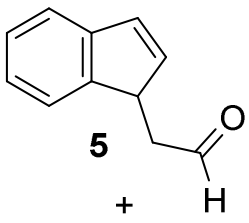

$\mathrm{H}_{2} \mathrm{~N}-\mathrm{R}$

6

Scheme 3. Retrosynthetic strategy for the preparation of indenylethylamido titanium complexes.

Herein we describe the first preparative example of a general method for the synthesis of indenylethylamido dichloro titanium complexes of type $\mathbf{2}$ that relies on the reaction of titanium tetrachloride with dilithiated indenylethylamines 3 or 4 (Scheme 3). In addition, we present a new and highly flexible method for the synthesis of indenylethylamines $\mathbf{3 / 4}$ which are needed as ligand precursors for the planned synthesis of additional new titanium complexes. As the keystep for the formation of the indenylethylamines $\mathbf{3 / 4}$, a reductive amination of 2 - $(1 H$-inden-1yl)acetaldehyde (5) with widely available primary amines $\mathbf{6}$ is used. This highly flexible reaction 
offers a simple way to alter the nature of the substituent $\mathrm{R}$ bound to the nitrogen atom of the indenylethylamines $\mathbf{3 / 4}$.

\section{Results and Discussion}

To the best of our knowledge, only one procedure for the synthesis of the desired aldehyde $\mathbf{5}$ can be found in the literature. The corresponding report by Ipaktschi describes a photochemical ring opening of benzonorbornanone (11) using a $450 \mathrm{~W}$ mercury high pressure lamp that directly converts 11 into 5 (Scheme 4). ${ }^{15}$ Our synthesis of the required starting material 11 began with a Diels-Alder reaction between cyclopentadiene (8) and benzyne which can easily be generated in situ from 1,2-dibromobenzene (7) and $n$-butyllithium. ${ }^{16}$ After the resulting benzonorbornadiene (9) had been obtained in moderate yield of $58 \%$ an oxymercuration and a subsequent Swern oxidation gave access to ketone $\mathbf{1 1}$ in $68 \%$ combined yield over these two steps. For the final photochemical ring opening, ketone 11 was then irradiated with UV-light in diethyl ether using a $450 \mathrm{~W}$ mercury high pressure lamp. As monitored by ${ }^{1} \mathrm{H}$ NMR spectroscopy, a reaction time of $24 \mathrm{~h}$ was necessary to reach full conversion. Finally, distillation of the crude product delivered the pure aldehyde 5 in $75 \%$ yield. Although the described four-step protocol can be used successfully for the multi-gram synthesis of aldehyde 5, the low overall yield of only $30 \%$ and the time consuming experimental procedures as well as the expensive starting materials must be regarded as severe drawbacks to this synthetic approach.
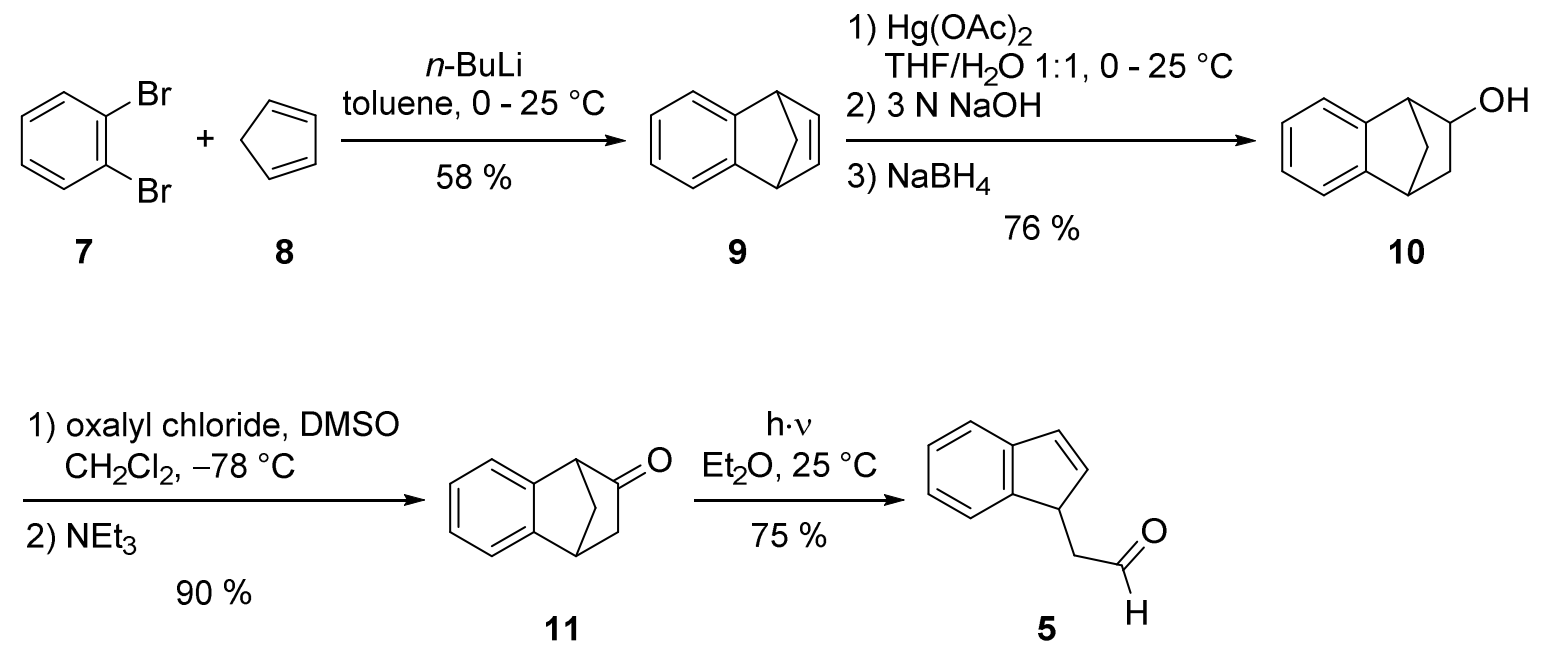

Scheme 4. Initially performed four-step synthesis of aldehyde $\mathbf{5}$.

In search of a more convenient synthesis of aldehyde $\mathbf{5}$, we then found that lithiated indene (12) smoothly undergoes a nucleophilic substitution reaction with commercially available and inexpensive 2-bromo-1,1-diethoxyethane (13) to give the corresponding indenylethylacetal 14 in 
excellent yield of $98 \%$ (Scheme 5). After aqueous work-up, acetal 14 was already obtained with high purity ( $97 \%$ as determined by GC analysis) and therefore, the crude product could directly be used for the subsequent acetal cleavage. For that purpose, acetal 14 was stirred in acetone in the presence of a catalytic amount of iodine $(10 \mathrm{~mol} \%)$ at $40{ }^{\circ} \mathrm{C}$ for $2 \mathrm{~h}^{17}$ Although aldehyde 5 could only be isolated in moderate yield of $58 \%$ from the crude reaction mixture, the new and shorter two-step synthesis of $\mathbf{5}$ gave a significantly improved overall yield of $57 \%$ and it is less time-consuming than the four-step alternative.

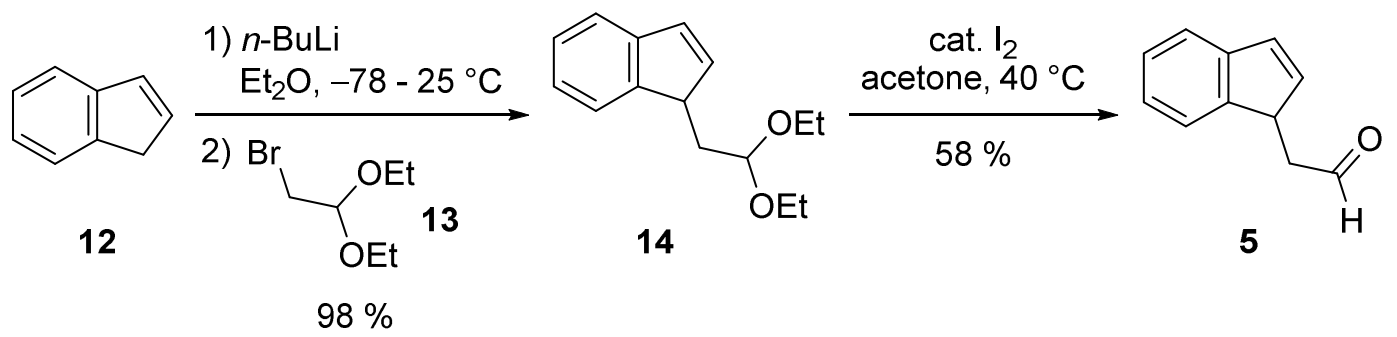

Scheme 5. Optimized two-step synthesis of aldehyde 5.

With key-intermediate 5 in hand we then performed a number of reductive aminations ${ }^{18}$ with various primary aryl- and alkylamines (Table 1). All reactions were carried out under ambient conditions and the progress of the reactions was monitored by TLC analysis. As expected, treatment of a solution of aldehyde $\mathbf{5}$ in methanol with the corresponding amines $\mathbf{6 a}-\mathbf{h}$ and subsequent reduction with a solution of $\mathrm{NaBH}_{3} \mathrm{CN}$ and $\mathrm{ZnCl}_{2}$ in methanol gave the amination products 3a-c and 4d-h in moderate to excellent yields (51-91 \%). Interestingly, the use of arylamines always resulted in the selective formation of the corresponding 1-isomer (3a-c) of the amination products (Table 1, entries 1-3) whereas most of the more basic pyridinyl- and alkylamines were converted to the thermodynamically more stable 3-isomers (4d-g, Table 1, entries 4-7). Only the reaction of the chiral substrate $(R)$-1-phenylethylamine (6h) with aldehyde 5 gave a mixture of the corresponding 1- and 3-isomer $3 \mathbf{h}$ and $\mathbf{4 h}$ in a ratio of 16:84 (Table 1, entry 8). Although the products 3a-c and $\mathbf{4 d - h}$ were fully characterized by $\mathrm{IR},{ }^{1} \mathrm{H}$ and ${ }^{13} \mathrm{C}$ NMR spectroscopy and mass spectrometry it can be noted that a single-crystal X-ray structure analysis of the hydrochloride of product $\mathbf{4 h}(\mathbf{4 h} \cdot \mathbf{H C l})$ could additionally be obtained (for details, see the supplementary material). To find out whether the reductive amination can also be used for the synthesis of multi-gram quantities of the desired products we additionally performed two selected reactions on a $30 \mathrm{mmol}$ scale. For that purpose, we chose aniline (6a) and isopropylamine (6e) as typical examples of aryl- and alkylamines. Gratifyingly, both reactions proceeded smoothly and the products 3a and 4e were obtained in yields of $89 \%$ and $59 \%$, respectively. These results which are even slightly better than those presented in Table 1 (entries 1 and 5) clearly prove that the new process can deliver sufficient quantities of indenylethylamines for the planned investigation of this class of compounds as ligand precursors in transition metal chemistry. 
Table 1. Reductive amination of aldehyde 5 with selected primary amines

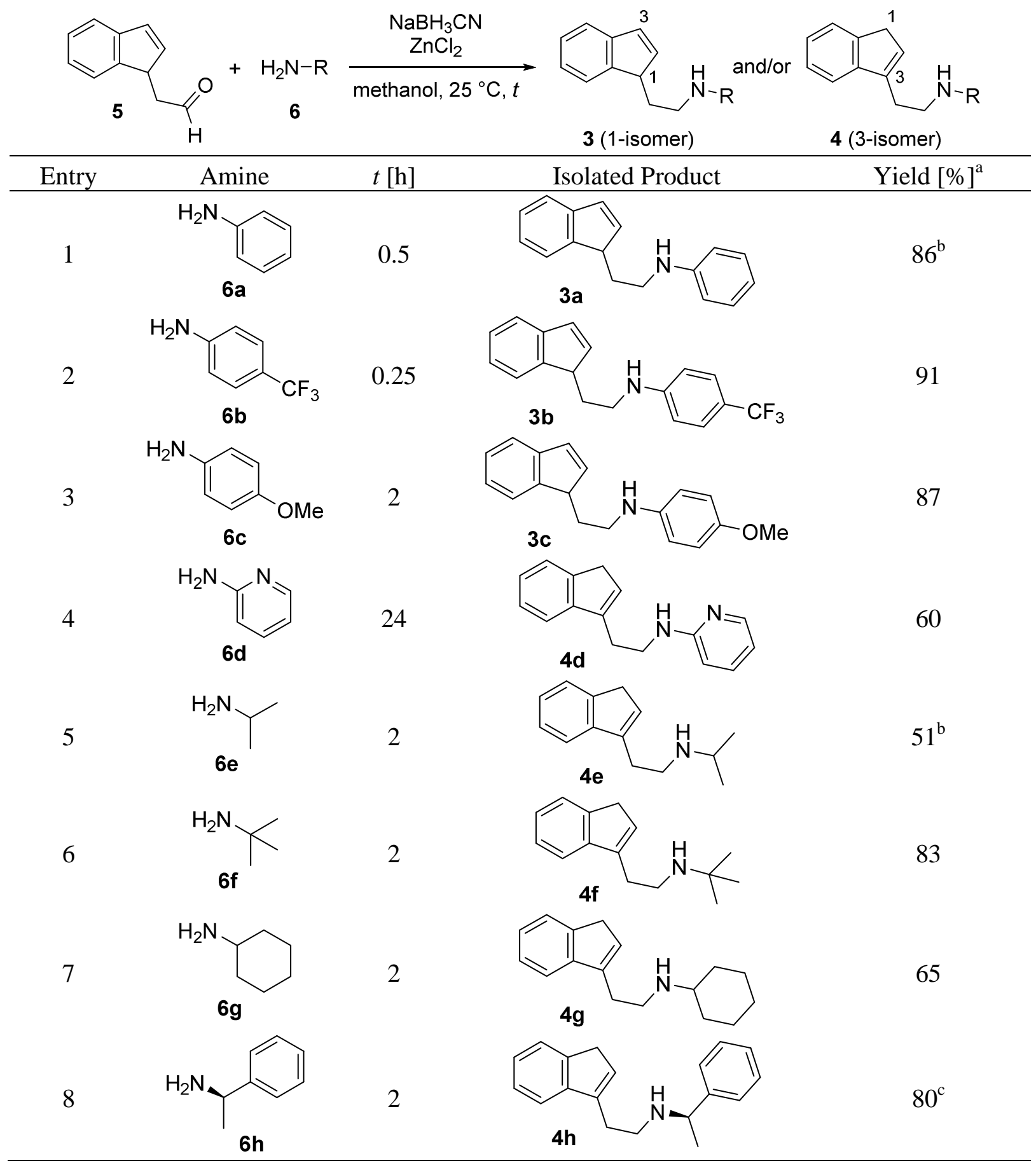

${ }^{\mathrm{a}}$ Reaction conditions: 1) amine (4.5 mmol), aldehyde 5 (3.0 mmol), $\mathrm{MeOH}(6 \mathrm{~mL}), 25{ }^{\circ} \mathrm{C}, 5$ min; 2) $\mathrm{NaBH}_{3} \mathrm{CN}$ (3.3 mmol), $\mathrm{ZnCl}_{2}(1.7 \mathrm{mmol}), \mathrm{MeOH}(6 \mathrm{~mL}), 25{ }^{\circ} \mathrm{C}, 0.25-24 \mathrm{~h}$; isolated yield. ${ }^{\mathrm{b}}$ The reaction was also carried out on a $30 \mathrm{mmol}$ scale with a slightly better yield. ${ }^{\mathrm{c}}$ Only major isomer presented. A mixture of the 1 - and the 3 -isomer in a ratio of $\mathbf{3 h} / \mathbf{4 h}=16: 84$ (GC analysis) was obtained. 
To finally prove the general suitability of the synthesized indenylethylamines as ligand precursors for the preparation of transition metal complexes we converted compound 3a with two equivalents of $n$-butyllithium into the corresponding dilithium salt (15) and treated it with titanium tetrachloride in diethyl ether (Scheme 6).

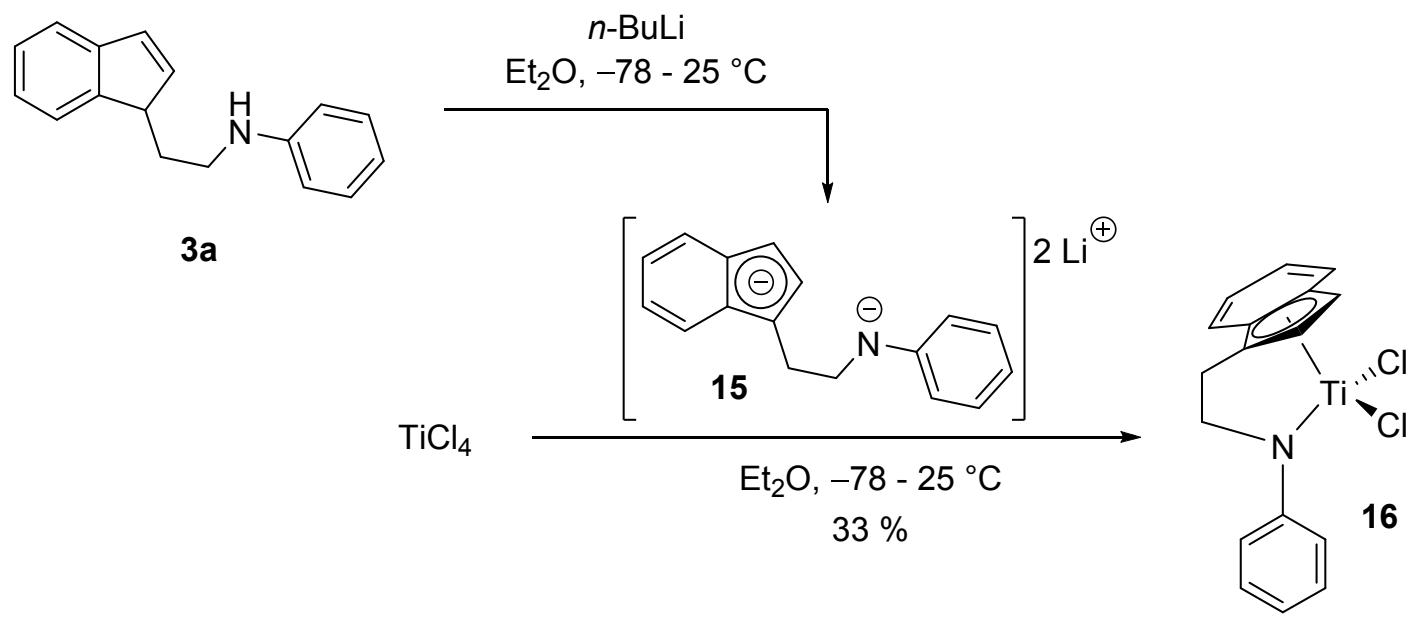

Scheme 6. Synthesis of the representative indenylethylamido complex 16.

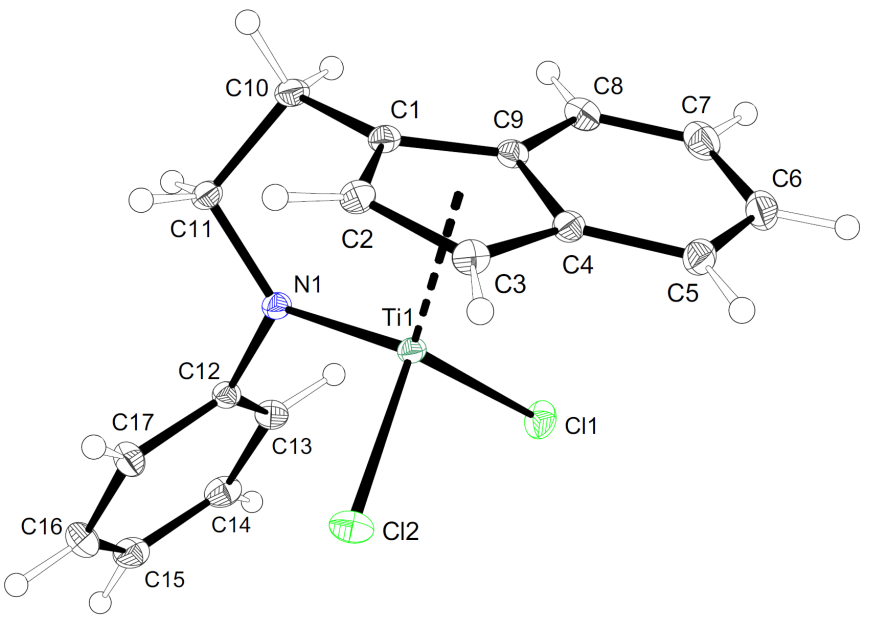

Figure 1. X-ray crystal structure of indenylethylamido complex 16. Ellipsoids are drawn at the $50 \%$ probability level (grey, $\mathrm{C}$ - white, $\mathrm{H}$ - green, $\mathrm{Cl}$ - blue, $\mathrm{N}$ - teal, Ti). Selected bond lengths [Å] and angles [ ${ }^{\circ}$ ]: Ti1-N1 1.8934(4), Ti1-Ct 2.029, Ti1-Cl1 2.2706(2), Ti1-Cl2 2.2898(2); N1Ti1-Ct 104.7, N1-Ti1-Cl1 105.55(1), N1-Ti1-Cl2 104.88(1), Cl1-Ti1-Cl2 103.82(1), C11-N1-Ti1 127.60(3), C12-N1-Ti1 116.81(3), N1-C11-C10 107.50(4) [Ct is the centroid of the fivemembered ring $\mathrm{C} 1-\mathrm{C} 4, \mathrm{C} 9]^{19}$

After separation from the formed lithium chloride, red-brown crystals of the expected new titanium complex 16 could be isolated in $33 \%$ yield. Subsequently, the obtained solid material could be recrystallized from benzene- $\mathrm{d}_{6}$ to give red crystals that were suitable for X-ray single- 
crystal analysis. The solid-state structure of $\mathbf{1 6}$ (Figure 1$)^{19}$ reveals a slightly distorted tetrahedral geometry around the titanium center and proves the bidentate binding mode of the new indenylethylamido ligand. In this context, it must be noted that although silyl-linked amido cyclopentadienyl and amido indenyl complexes are well known, ${ }^{14}$ corresponding complexes with aryl substituents bound to the nitrogen atom of the bidentate ligand are extremely rare in the literature. ${ }^{20-23}$

\section{Conclusions}

In summary, it was shown that the reductive amination of 2-(1H-inden-1-yl)acetaldehyde (5) with commercially available primary amines represents a highly flexible and efficient method for the synthesis of various indenylethylamines and in addition, a new two-step synthesis of aldehyde 5 that uses inexpensive indene and 2-bromo-1,1-diethoxyethane as starting materials was developed. Particularly noteworthy is that a selected indenylethylamine could already be used as a ligand precursor for the synthesis of a corresponding indenylethylamido titanium complex. This result clearly proves the suitability of indenylethylamines as starting materials for the synthesis of transition metal complexes and it paves the way for the planned investigation of corresponding complexes as catalysts for hydroaminoalkylation reactions of alkenes.

\section{Experimental Section}

General: All air and moisture sensitive reactions were carried out under an atmosphere of argon using standard Schlenk line techniques. Unless otherwise noted, all chemicals were purchased from commercial sources and were used without further purification. Cyclopentadiene was freshly distilled from dicyclopentadiene (93\%, stabilized) and iron powder under an argon atmosphere. Indene (90\%, stabilized) was purified by distillation ( $25 \mathrm{~cm}$ Vigreux column) at $3.00 \mathrm{mmHg}$ and stored under an argon atmosphere over molecular sieves $(4 \AA)$ at $-30{ }^{\circ} \mathrm{C}$ prior to use. All amines were purified by Kugelrohr distillation, degassed (freeze, pump, thaw) and stored under an argon atmosphere. Dichloromethane (99.8\%, extra dry with molecular sieves) was purchased from Acros Organics and used as received. DMSO was distilled from $\mathrm{CaH}_{2}$ and stored under an argon atmosphere over molecular sieves ( $4 \AA$ ) prior to use. Diethyl ether, toluene and benzene- $\mathrm{d}_{6}$ were dried by distillation from sodium. Light petroleum ether (PE) and tert-butyl methyl ether (MTBE) for flash chromatography were purified by distillation. Flash chromatography was carried out with a Büchi Sepacore ${ }^{\circledR}$ Flash System X10 using Büchi Sepacore ${ }^{\circledR}$ Flash Cartridges (40 g silica gel) or Büchi PLASTIGLAS ${ }^{\circledR}$ columns with silica gel from Fluka (particle size 0.037-0.063 mm). For thin layer chromatography, ALUGRAM ${ }^{\circledR}$ TLC $^{2}$ aluminium sheets with fluorescent indicator $(254 \mathrm{~nm})$ from Macherey-Nagel were used. All substances were detected with UV light. As light source for the photochemical reaction a water- 
cooled Hanovia L 469 A $450 \mathrm{~W}$ mercury high pressure lamp was used. Melting points were determined with a Schorpp-Gerätetechnik melting point MPM-H2 apparatus and are uncorrected. IR spectra were recorded with a Bruker Tensor 27 spectrometer using an attenuated total reflection (ATR) method. Absorption values are given as wavenumbers $\left(\mathrm{cm}^{-1}\right)$. The intensities of the absorptions are given as weak (w), medium (m), strong (s), very strong (vs) and broad (br). NMR spectra were recorded with a Bruker Avance DRX or a Bruker Avance III spectrometer $\left({ }^{1} \mathrm{H}, 499.9 \mathrm{MHz} ;{ }^{13} \mathrm{C}, 125.7 \mathrm{MHz} ;{ }^{19} \mathrm{~F}, 470.3 \mathrm{MHz}\right)$ at $298 \mathrm{~K}$. Chemical shifts $(\delta)$ are reported in ppm relative to the solvent residual peak of $\mathrm{CDCl}_{3}\left({ }^{1} \mathrm{H}, 7.26 \mathrm{ppm} ;{ }^{13} \mathrm{C}, 77.00 \mathrm{ppm}\right)$, benzene- $\mathrm{d}_{6}$ $\left({ }^{1} \mathrm{H}, 7.16 \mathrm{ppm} ;{ }^{13} \mathrm{C}, 128.00 \mathrm{ppm}\right)$ or the signal of ferrocene $\left({ }^{1} \mathrm{H}, 4.00 \mathrm{ppm}\right)$ or $\mathrm{CFCl}_{3}\left({ }^{19} \mathrm{~F}, 0.00\right.$ ppm). Multiplicities are reported using the following abbreviations: $s$, singlet; $d$, doublet; $t$, triplet; q, quartet; hept, heptet; m, multiplet; br., broad signal or their combinations. Coupling constants $(J)$ are reported in Hz. The assignments of the multiplicities are based on DEPT, COSY, HMQC and HMBC spectra. Mass spectra (MS) or high-resolution mass spectra (HRMS) were recorded on a Finnigan MAT 95 spectrometer (EI) with an optional Linden CMS source (LIFDI) or on a Waters Q-TOF Premier spectrometer (ESI). GC analyses were performed on a Shimadzu GC-2010 plus gas chromatograph with a flame ionization detector.

Tricyclo[6.2.1.0 ${ }^{\mathbf{2}, 7}$ ]undeca-2,4,6,9-tetraene (9). ${ }^{16}$ A flame-dried $500 \mathrm{~mL}$ three-necked roundbottom flask equipped with a Teflon ${ }^{\circledR}$-coated oval stirring bar $(2.5 \mathrm{~cm})$, a septum, an argon-inlet and a dropping-funnel was charged with 1,2-dibromobenzene (7, $50.00 \mathrm{~g}, 212.0 \mathrm{mmol}$ ), freshly distilled cyclopentadiene $(\mathbf{8}, 14.01 \mathrm{~g}, 212.0 \mathrm{mmol})$ and toluene $(250 \mathrm{~mL})$. The flask was cooled to $0{ }^{\circ} \mathrm{C}$ and a solution of $n$-butyllithium $\left(58.50 \mathrm{~g}, c=2.5 \mathrm{~mol} \cdot \mathrm{L}^{-1}\right.$ in hexanes, $\left.212.0 \mathrm{mmol}\right)$ was added dropwise over a period of 30 minutes. After the resulting white suspension had been stirred at $0{ }^{\circ} \mathrm{C}$ for additional ten minutes, the mixture was allowed to reach $25{ }^{\circ} \mathrm{C}$ and stirred overnight. Water $(150 \mathrm{~mL})$ was added and the layers were separated. The aqueous layer was extracted with PE $(3 \times 50 \mathrm{~mL})$ and the combined organic layers were dried with $\mathrm{MgSO}_{4}$, filtered and concentrated under vacuum. The crude product was purified by flash chromatography $\left(\mathrm{SiO}_{2}\right.$, $\mathrm{PE})$ to give product $9(17.45 \mathrm{~g}, 122.7 \mathrm{mmol}, 58 \%)$ as a colorless oil. $\mathrm{R}_{\mathrm{f}} 0.34\left(\mathrm{SiO}_{2}, \mathrm{PE}\right)$; IR (ATR, $v_{\max }, \mathrm{cm}^{-1}$ ): 3067 (w), $2982(\mathrm{w}), 2934$ (w), 2866 (w), 1454 (s), 1303 (s), 1007 (m), 830 (s); ${ }^{1} \mathrm{H}$ NMR $\left(499.9 \mathrm{MHz}, \mathrm{CDCl}_{3}\right): \delta_{\mathrm{H}} 2.28\left(1 \mathrm{H}, \mathrm{d},{ }^{2} J_{\mathrm{H}, \mathrm{H}} 7.0 \mathrm{~Hz}, \mathrm{CH}_{2}\right), 2.36\left(1 \mathrm{H}, \mathrm{d},{ }^{2} J_{\mathrm{H}, \mathrm{H}} 7.0 \mathrm{~Hz}\right.$, $\left.\mathrm{CH}_{2}\right), 3.92(2 \mathrm{H}, \mathrm{s}, 2 \mathrm{CH}), 6.83(2 \mathrm{H}, \mathrm{s}, 2 \mathrm{CH}), 6.94-6.99(2 \mathrm{H}, \mathrm{m}, 2 \mathrm{CH}), 7.24-7.29(2 \mathrm{H}, \mathrm{m}, 2 \mathrm{CH})$; ${ }^{13} \mathrm{C}$ NMR $\left(125.7 \mathrm{MHz}, \mathrm{CDCl}_{3}\right): \delta_{\mathrm{C}} 50.3(\mathrm{CH}), 70.1\left(\mathrm{CH}_{2}\right), 121.5(\mathrm{CH}), 124.2(\mathrm{CH}), 143.0(\mathrm{CH})$, $151.8(\mathrm{C})$.

Tricyclo[6.2.1.0 $\left.{ }^{2,7}\right]$ undeca-2,4,6-trien-9-ol (10). ${ }^{24}$ A $1000 \mathrm{~mL}$ round-bottom flask equipped with a Teflon ${ }^{\circledR}$-coated oval stirring bar $(2.5 \mathrm{~cm})$ was charged with mercury(II) acetate $(38.32 \mathrm{~g}$, $120.3 \mathrm{mmol})$ and water $(125 \mathrm{~mL})$ followed by THF $(125 \mathrm{~mL})$ to form an orange suspension which was cooled to $0{ }^{\circ} \mathrm{C}$. Alkene $9(17.10 \mathrm{~g}, 120.3 \mathrm{mmol})$ was added dropwise and the resulting mixture was stirred at $25{ }^{\circ} \mathrm{C}$ for two hours to give a clear solution which was then treated with 3 $\mathrm{N} \mathrm{NaOH}(125 \mathrm{~mL})$ and a solution of sodium borohydride $(2.28 \mathrm{~g}, 60.1 \mathrm{mmol})$ in $3 \mathrm{~N} \mathrm{NaOH}(125$ $\mathrm{mL})$. After this mixture had been stirred for an additional hour, the resulting aqueous solution was decanted from precipitated mercury, saturated with sodium chloride and extracted with 
MTBE $(2 \times 100 \mathrm{~mL})$. The combined organic layers were dried with $\mathrm{MgSO}_{4}$, filtered and concentrated under vacuum. The crude product was purified by flash chromatography $\left(\mathrm{SiO}_{2}\right.$, $\mathrm{PE} / \mathrm{MTBE} 4: 1 \rightarrow 1: 2)$ and the obtained yellow solid was washed several times with $\mathrm{PE}$ at $0{ }^{\circ} \mathrm{C}$ to give product $10(14.70 \mathrm{~g}, 91.7 \mathrm{mmol}, 76 \%)$ as a colorless solid. $\mathrm{R}_{\mathrm{f}} 0.37\left(\mathrm{SiO}_{2}, \mathrm{PE} / \mathrm{MTBE} 2: 1\right)$;

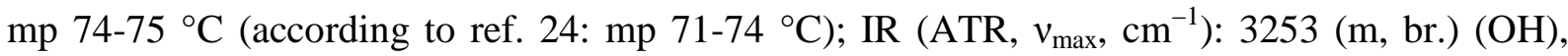
3072 (w), 3022 (w), 2962 (m), 2926 (m), 2875 (w), 2855 (w), 1470 (m), 1456 (m), 1407 (m), 1327 (m), 1285 (s), 1226 (m), 1075 (vs), 1045 (vs), 969 (vs); ${ }^{1} \mathrm{H}$ NMR (499.9 MHz, CDCl ${ }_{3}$ ): $\delta_{\mathrm{H}}$ $1.64\left(1 \mathrm{H}, \mathrm{ddd},{ }^{2} J_{\mathrm{H}, \mathrm{H}} 12.5 \mathrm{~Hz},{ }^{3} J_{\mathrm{H}, \mathrm{H}} 3.9 \mathrm{~Hz},{ }^{3} J_{\mathrm{H}, \mathrm{H}} 2.3 \mathrm{~Hz}, \mathrm{CH}_{2}\right), 1.82\left(1 \mathrm{H}, \mathrm{ddd},{ }^{2} J_{\mathrm{H}, \mathrm{H}} 12.5 \mathrm{~Hz},{ }^{3} J_{\mathrm{H}, \mathrm{H}}\right.$ $\left.6.7 \mathrm{~Hz},{ }^{3} J_{\mathrm{H}, \mathrm{H}} 2.5 \mathrm{~Hz}, \mathrm{CH}_{2}\right), 1.90-1.94\left(1 \mathrm{H}, \mathrm{m}, \mathrm{CH}_{2}\right), 2.09(1 \mathrm{H}, \mathrm{s}, \mathrm{OH}), 2.11\left(1 \mathrm{H}, \mathrm{dt},{ }^{2} J_{\mathrm{H}, \mathrm{H}} 9.1 \mathrm{~Hz}\right.$, $\left.{ }^{3} J_{\mathrm{H}, \mathrm{H}} 1.3 \mathrm{~Hz}, \mathrm{CH}_{2}\right), 3.25(1 \mathrm{H}, \mathrm{s}, \mathrm{CH}), 3.31-3.35(1 \mathrm{H}, \mathrm{m}, \mathrm{CH}), 3.99\left(1 \mathrm{H}, \mathrm{d},{ }^{3} J_{\mathrm{H}, \mathrm{H}} 6.6 \mathrm{~Hz}, \mathrm{CH}\right)$, 7.03-7.11 (2H, m, 2CH), 7.12-7.17 (1H, m, CH), 7.18-7.23 (1H, m, CH); ${ }^{13} \mathrm{C} \mathrm{NMR}(125.7 \mathrm{MHz}$, $\left.\mathrm{CDCl}_{3}\right): \delta_{\mathrm{C}} 39.7\left(\mathrm{CH}_{2}\right), 42.9(\mathrm{CH}), 45.9\left(\mathrm{CH}_{2}\right), 52.2(\mathrm{CH}), 73.4(\mathrm{CH}), 120.6(\mathrm{CH}), 122.0(\mathrm{CH})$, $125.5(\mathrm{CH}), 126.1(\mathrm{CH}), 144.4(\mathrm{C}), 149.4(\mathrm{C})$.

Tricyclo[6.2.1.0 $\left.{ }^{\mathbf{2}, 7}\right]$ undeca-2,4,6-trien-9-one (11). ${ }^{25}$ A flame-dried $1000 \mathrm{~mL}$ round-bottom Schlenk-flask equipped with a Teflon ${ }^{\circledR}$-coated oval stirring bar $(2.5 \mathrm{~cm})$ and a septum was charged with oxalyl chloride $(11.13 \mathrm{~g}, 87.7 \mathrm{mmol})$ and $\mathrm{CH}_{2} \mathrm{Cl}_{2}(200 \mathrm{~mL})$ and was cooled to -78 ${ }^{\circ} \mathrm{C}$. A solution of dimethyl sulfoxide $(13.71 \mathrm{~g}, 175.4 \mathrm{mmol})$ in $\mathrm{CH}_{2} \mathrm{Cl}_{2}(40 \mathrm{~mL})$ was added over a period of five minutes via syringe and the resulting mixture was stirred for 15 minutes. A solution of alcohol $10(12.78 \mathrm{~g}, 79.7 \mathrm{mmol})$ in $\mathrm{CH}_{2} \mathrm{Cl}_{2}(80 \mathrm{~mL})$ was added in portions over a period of five minutes via syringe to form a white suspension which was stirred for 15 minutes. Then triethylamine $(40.35 \mathrm{~g}, 398.7 \mathrm{mmol}$ ) was added and the mixture was stirred for additional five minutes at $-78{ }^{\circ} \mathrm{C}$. The mixture was then allowed to reach $25^{\circ} \mathrm{C}$ and water $(400 \mathrm{~mL})$ was added. The organic layer was separated and the aqueous layer was extracted with $\mathrm{CH}_{2} \mathrm{Cl}_{2}(400$ $\mathrm{mL})$. The combined organic layers were washed with brine $(400 \mathrm{~mL})$, diluted sulfuric acid $(1 \%$, $400 \mathrm{~mL})$, water $(400 \mathrm{~mL})$ and aqueous $\mathrm{NaHCO}_{3}(5 \%, 400 \mathrm{~mL})$, dried with $\mathrm{MgSO}_{4}$, filtered and concentrated under vacuum. The crude product was purified by flash chromatography $\left(\mathrm{SiO}_{2}\right.$, PE/MTBE 9:1 $\rightarrow 1: 1)$ to give product $11(12.98 \mathrm{~g}, 82.1 \mathrm{mmol}, 90 \%)$ as a pale yellow oil. $\mathrm{R}_{\mathrm{f}} 0.21$ $\left(\mathrm{SiO}_{2}, \mathrm{PE} / \mathrm{MTBE}\right.$ 9:1); IR (ATR, $v_{\max }, \mathrm{cm}^{-1}$ ): 3069 (w), 3046 (w), 2973 (w), 2946 (w), 2918 (w), 2878 (w), 1742 (vs) (C=O), 1465 (m), 1460 (m), 1275 (m), 1122 (s), 979 (s); ${ }^{1} \mathrm{H}$ NMR (499.9 $\left.\mathrm{MHz} \mathrm{CDCl}_{3}\right): \delta_{\mathrm{H}} 1.96\left(1 \mathrm{H}, \mathrm{dd},{ }^{2} J_{\mathrm{H}, \mathrm{H}} 17.0 \mathrm{~Hz},{ }^{3} J_{\mathrm{H}, \mathrm{H}} 4.5 \mathrm{~Hz}, \mathrm{CH}_{2}\right), 2.26\left(1 \mathrm{H}, \mathrm{dt},{ }^{2} J_{\mathrm{H}, \mathrm{H}} 9.6 \mathrm{~Hz}\right.$, $\left.{ }^{3} J_{\mathrm{H}, \mathrm{H}} 1.3 \mathrm{~Hz}, \mathrm{CH}_{2}\right), 2.30\left(1 \mathrm{H}, \mathrm{dd},{ }^{2} J_{\mathrm{H}, \mathrm{H}} 17.0 \mathrm{~Hz},{ }^{3} J_{\mathrm{H}, \mathrm{H}} 3.9 \mathrm{~Hz}, \mathrm{CH}_{2}\right), 2.43-2.49\left(1 \mathrm{H}, \mathrm{m}, \mathrm{CH}_{2}\right), 3.57$ $(1 \mathrm{H}, \mathrm{s}, \mathrm{CH}), 3.64-3.68(1 \mathrm{H}, \mathrm{m}, \mathrm{CH}), 7.11\left(1 \mathrm{H}, \mathrm{td},{ }^{3} J_{\mathrm{H}, \mathrm{H}} 7.6 \mathrm{~Hz},{ }^{4} J_{\mathrm{H}, \mathrm{H}} 1.2 \mathrm{~Hz}, \mathrm{CH}\right), 7.15(1 \mathrm{H}, \mathrm{td}$, $\left.{ }^{3} J_{\mathrm{H}, \mathrm{H}} 7.6 \mathrm{~Hz},{ }^{4} J_{\mathrm{H}, \mathrm{H}} 1.2 \mathrm{~Hz}, \mathrm{CH}\right), 7.24-7.30(2 \mathrm{H}, \mathrm{m}, 2 \mathrm{CH}) ;{ }^{13} \mathrm{C} \mathrm{NMR}\left(125.7 \mathrm{MHz}, \mathrm{CDCl}_{3}\right): \delta_{\mathrm{C}} 40.2$ $\left(\mathrm{CH}_{2}\right), 41.6(\mathrm{CH}), 50.6\left(\mathrm{CH}_{2}\right), 57.8(\mathrm{CH}), 121.4(\mathrm{CH}), 123.4(\mathrm{CH}), 126.5(\mathrm{CH}), 127.2(\mathrm{CH})$, $139.6(\mathrm{C}), 148.5(\mathrm{C}), 213.3(\mathrm{C}=\mathrm{O})$.

1-(2,2-Diethoxyethyl)-1H-indene (14). A flame-dried $1000 \mathrm{~mL}$ round-bottom Schlenk-flask equipped with a Teflon ${ }^{\circledR}$-coated stirring bar $(4 \mathrm{~cm})$ and a septum was charged with indene (12, $16.84 \mathrm{~g}, 145.0 \mathrm{mmol})$ and diethyl ether $(250 \mathrm{~mL})$ and was cooled to $-78{ }^{\circ} \mathrm{C}$. A solution of $n$ butyllithium (44.02 $\mathrm{g}, c=2.5 \mathrm{~mol} \cdot \mathrm{L}^{-1}$ in hexanes, $159.5 \mathrm{mmol}$ ) was added via syringe and the reaction mixture was allowed to reach $25{ }^{\circ} \mathrm{C}$ to form an orange solution. After the mixture had 
been stirred at room temperature for two hours the flask was cooled to $-78{ }^{\circ} \mathrm{C}$ and 2-bromo-1,1diethoxyethane $(13,28.58 \mathrm{~g}, 145.0 \mathrm{mmol})$ was added via syringe. Then the reaction mixture was allowed to reach $25{ }^{\circ} \mathrm{C}$ and stirring at room temperature was continued for one hour. The resulting red solution was carefully hydrolyzed with water $(200 \mathrm{~mL})$ and the layers were separated. The aqueous layer was extracted with diethyl ether $(2 \times 100 \mathrm{~mL})$ and the combined organic layers were washed with brine $(200 \mathrm{~mL})$, dried with $\mathrm{MgSO}_{4}$ and filtered. Concentration under vacuum gave the acetal $14(33.10 \mathrm{~g}, 142.5 \mathrm{mmol}, 98 \%)$ as a yellow oil with a purity of 97 $\%$ (GC). This material was used without further purification for the subsequent acetal cleavage. IR (ATR, $v_{\max }, \mathrm{cm}^{-1}$ ): 3067 (w), 2976 (w), 2929 (w), 2877 (w), 1128 (s), 1057 (vs), 1019 (s), 776 (vs); ${ }^{1} \mathrm{H}$ NMR $\left(499.9 \mathrm{MHz}, \mathrm{CDCl}_{3}\right): \delta_{\mathrm{H}} 1.21\left(3 \mathrm{H}, \mathrm{t},{ }^{3} J_{\mathrm{H}, \mathrm{H}} 7.1 \mathrm{~Hz}, \mathrm{CH}_{3}\right), 1.25\left(3 \mathrm{H}, \mathrm{t},{ }^{3} J_{\mathrm{H}, \mathrm{H}} 7.1 \mathrm{~Hz}\right.$, $\left.\mathrm{CH}_{3}\right), 1.68-1.76\left(1 \mathrm{H}, \mathrm{m}, \mathrm{CH}_{2}\right), 2.20-2.27\left(1 \mathrm{H}, \mathrm{m}, \mathrm{CH}_{2}\right), 3.47-3.61\left(3 \mathrm{H}, \mathrm{m}, \mathrm{CH}, \mathrm{CH}_{2}\right), 3.63-3.77$ $\left(2 \mathrm{H}, \mathrm{m}, \mathrm{CH}_{2}\right), 4.66-4.72(1 \mathrm{H}, \mathrm{m}, \mathrm{CH}), 6.62\left(1 \mathrm{H}, \mathrm{dd},{ }^{3} J_{\mathrm{H}, \mathrm{H}} 5.5 \mathrm{~Hz},{ }^{3} J_{\mathrm{H}, \mathrm{H}} 1.8 \mathrm{~Hz}, \mathrm{CH}\right), 6.62(1 \mathrm{H}$, $\left.\mathrm{dd},{ }^{3} J_{\mathrm{H}, \mathrm{H}} 5.5 \mathrm{~Hz},{ }^{4} J_{\mathrm{H}, \mathrm{H}} 1.6 \mathrm{~Hz}, \mathrm{CH}\right), 7.20\left(1 \mathrm{H}, \mathrm{td},{ }^{3} J_{\mathrm{H}, \mathrm{H}} 7.4 \mathrm{~Hz},{ }^{4} J_{\mathrm{H}, \mathrm{H}} 1.0 \mathrm{~Hz}, \mathrm{CH}\right), 7.23-7.28(1 \mathrm{H}$, $\mathrm{m}, \mathrm{CH}), 7.36\left(1 \mathrm{H}, \mathrm{d},{ }^{3} J_{\mathrm{H}, \mathrm{H}} 7.4 \mathrm{~Hz}, \mathrm{CH}\right), 7.44\left(1 \mathrm{H}, \mathrm{d},{ }^{3} J_{\mathrm{H}, \mathrm{H}} 7.4 \mathrm{~Hz}, \mathrm{CH}\right) ;{ }^{13} \mathrm{C} \mathrm{NMR}(125.7 \mathrm{MHz}$, $\left.\mathrm{CDCl}_{3}\right): \delta_{\mathrm{C}} 15.3\left(\mathrm{CH}_{3}\right), 15.4\left(\mathrm{CH}_{3}\right), 35.5\left(\mathrm{CH}_{2}\right), 46.6(\mathrm{CH}), 61.2\left(\mathrm{CH}_{2}\right), 61.4\left(\mathrm{CH}_{2}\right), 102.2(\mathrm{CH})$, $121.0(\mathrm{CH}), 122.9(\mathrm{CH}), 124.7(\mathrm{CH}), 126.5(\mathrm{CH}), 130.7(\mathrm{CH}), 139.1(\mathrm{CH}), 144.1(\mathrm{C}), 147.5(\mathrm{C})$; HRMS (ESI+) calcd. for $\left[\mathrm{C}_{15} \mathrm{H}_{20} \mathrm{O}_{2}+\mathrm{Na}\right]^{+}: 255.1361$. Found: 255.1363.

2-(1H-Inden-1-yl)acetaldehyde $(5) .{ }^{15}$ Method A: In a flame-dried $1500 \mathrm{~mL}$ three-necked tube equipped with a water-cooled $450 \mathrm{~W}$ Hg-high-pressure burner, a Teflon ${ }^{\circledR}$-coated stirring bar (4 $\mathrm{cm})$, a septum and an argon-inlet, ketone 11 (12.84 g, $81.2 \mathrm{mmol})$ was dissolved in diethyl ether (1.2 L). The mixture was irradiated at $25{ }^{\circ} \mathrm{C}$ for 24 hours (conversion was monitored by ${ }^{1} \mathrm{H}$ NMR spectroscopy) and afterwards, the solvent was removed under reduced pressure. Finally, the crude residue was distilled (17 cm Vigreux column, $0.011 \mathrm{mmHg}$ ) to give aldehyde $5(9.59 \mathrm{~g}$, $60.6 \mathrm{mmol}, 75 \%$ ) as a colorless oil. Method B: A $2000 \mathrm{~mL}$ round-bottom flask equipped with a Teflon ${ }^{\circledR}$-coated oval stirring bar $(4 \mathrm{~cm})$ was charged with acetone $(1000 \mathrm{~mL})$ and heated to 40 ${ }^{\circ} \mathrm{C}$. Diethyl acetal $14(17.42 \mathrm{~g}, 75.0 \mathrm{mmol})$ and iodine $(1.90 \mathrm{~g}, 7.5 \mathrm{mmol})$ were added and the resulting mixture was stirred for two hours at $40{ }^{\circ} \mathrm{C}$. Aqueous $\mathrm{Na}_{2} \mathrm{~S}_{2} \mathrm{O}_{3}$-solution $(5 \%, 500 \mathrm{~mL})$ was added and the mixture was stirred for additional 15 minutes at $25{ }^{\circ} \mathrm{C}$. Most of the acetone was then removed under reduced pressure and MTBE $(500 \mathrm{~mL})$ was added. The resulting layers were separated and the aqueous layer was extracted with MTBE $(150 \mathrm{~mL})$. The combined organic layers were washed with brine $(150 \mathrm{~mL})$, dried with $\mathrm{MgSO}_{4}$, filtered and concentrated under vacuum. To remove unreacted acetale 14, the crude product was purified by flash chromatography $\left(\mathrm{SiO}_{2}, \mathrm{PE} / \mathrm{MTBE} 19: 1 \rightarrow 1: 1\right)$. Finally, the obtained orange oil was distilled (17 cm Vigreux column, $0.011 \mathrm{mmHg})$ to give aldehyde $5(6.91 \mathrm{~g}, 43.7 \mathrm{mmol}, 58 \%)$ as a pale yellow oil. In both cases, aldehyde 5 was degassed (freeze, pump, thaw) and stored at $-30{ }^{\circ} \mathrm{C}$ under an atmosphere of argon. $\mathrm{R}_{\mathrm{f}} 0.23\left(\mathrm{SiO}_{2}\right.$, PE/MTBE 9:1); bp 68-69 ${ }^{\circ} \mathrm{C}$ at $0.011 \mathrm{mmHg}$ (according to ref. 15: bp $76-7{ }^{\circ} \mathrm{C}$ at $0.2 \mathrm{mmHg}$ ); IR (ATR, $v_{\max }, \mathrm{cm}^{-1}$ ): $3066(\mathrm{w}), 3013(\mathrm{w})$, 2888 (w), 2823 (w) (CHO), 2726 (w) (CHO), 1720 (vs) (C=O); ${ }^{1} \mathrm{H}$ NMR (499.9 MHz, $\mathrm{CDCl}_{3}$ ): $\delta_{\mathrm{H}} 2.67\left(1 \mathrm{H}, \mathrm{ddd},{ }^{2} J_{\mathrm{H}, \mathrm{H}} 17.6 \mathrm{~Hz},{ }^{3} J_{\mathrm{H}, \mathrm{H}} 7.9 \mathrm{~Hz},{ }^{3} J_{\mathrm{H}, \mathrm{H}} 1.4 \mathrm{~Hz}, \mathrm{CH}_{2}\right), 2.91\left(1 \mathrm{H}, \mathrm{ddd},{ }^{2} J_{\mathrm{H}, \mathrm{H}} 17.6 \mathrm{~Hz}\right.$, $\left.{ }^{3} J_{\mathrm{H}, \mathrm{H}} 5.9 \mathrm{~Hz},{ }^{3} J_{\mathrm{H}, \mathrm{H}} 1.4 \mathrm{~Hz}, \mathrm{CH}_{2}\right), 3.91-3.97(1 \mathrm{H}, \mathrm{m}, \mathrm{CH}), 6.54\left(1 \mathrm{H}, \mathrm{dd},{ }^{3} J_{\mathrm{H}, \mathrm{H}} 5.5 \mathrm{~Hz},{ }^{3} J_{\mathrm{H}, \mathrm{H}} 1.9 \mathrm{~Hz}\right.$, 
$\mathrm{CH}), 6.86\left(1 \mathrm{H}, \mathrm{dd},{ }^{3} J_{\mathrm{H}, \mathrm{H}} 5.5 \mathrm{~Hz},{ }^{4} J_{\mathrm{H}, \mathrm{H}} 1.8 \mathrm{~Hz}, \mathrm{CH}\right), 7.21\left(1 \mathrm{H}, \mathrm{td},{ }^{3} J_{\mathrm{H}, \mathrm{H}} 7.4 \mathrm{~Hz},{ }^{4} J_{\mathrm{H}, \mathrm{H}} 1.0 \mathrm{~Hz}, \mathrm{CH}\right)$, $7.29\left(1 \mathrm{H}, \mathrm{t},{ }^{3} J_{\mathrm{H}, \mathrm{H}} 7.4 \mathrm{~Hz}, \mathrm{CH}\right), 7.38\left(1 \mathrm{H}, \mathrm{d},{ }^{3} J_{\mathrm{H}, \mathrm{H}} 7.4 \mathrm{~Hz}, \mathrm{CH}\right), 7.41\left(1 \mathrm{H}, \mathrm{d},{ }^{3} J_{\mathrm{H}, \mathrm{H}} 7.4 \mathrm{~Hz}, \mathrm{CH}\right)$, $9.74\left(1 \mathrm{H}, \mathrm{t},{ }^{3} J_{\mathrm{H}, \mathrm{H}} 1.4 \mathrm{~Hz}, \mathrm{CHO}\right) ;{ }^{13} \mathrm{C} \mathrm{NMR}\left(125.7 \mathrm{MHz}, \mathrm{CDCl}_{3}\right): \delta_{\mathrm{C}} 44.2\left(\mathrm{CH}_{2}\right), 44.8(\mathrm{CH})$, $121.4(\mathrm{CH}), 123.0(\mathrm{CH}), 125.2(\mathrm{CH}), 127.0(\mathrm{CH}), 132.0(\mathrm{CH}), 137.7(\mathrm{CH}), 144.0(\mathrm{C}), 146.2(\mathrm{C})$, 201.0 (CHO).

General procedure for the reductive amination of aldehyde 5 with selected primary amines. A $50 \mathrm{~mL}$ round-bottom flask equipped with a Teflon ${ }^{\circledR}$-coated stirring bar $(1 \mathrm{~cm})$ was charged with the primary amine $(4.5 \mathrm{mmol})$ and methanol $(6 \mathrm{~mL})$. Aldehyde $5(475 \mathrm{mg}, 3.0 \mathrm{mmol})$ was added and the resulting solution was stirred for five minutes at $25{ }^{\circ} \mathrm{C}$. Then a solution of sodium cyanoborohydride (207 mg, $3.3 \mathrm{mmol})$ and zinc chloride $(225 \mathrm{mg}, 1.7 \mathrm{mmol})$ in methanol (6 $\mathrm{mL}$ ) was added dropwise and the solution was stirred for the appropriate time (see Table 1) at 25 ${ }^{\circ} \mathrm{C}$ (the conversion was monitored by TLC). The mixture was diluted with $0.1 \mathrm{~N} \mathrm{NaOH}(25 \mathrm{~mL})$ to form a white suspension which was extracted with MTBE $(3 \times 10 \mathrm{~mL})$. The combined organic layers were washed with water $(10 \mathrm{~mL})$ and brine $(10 \mathrm{~mL})$, dried with $\mathrm{MgSO}_{4}$, filtered and concentrated under vacuum to give the corresponding crude product which was purified by chromatography. All products were degassed (freeze, pump, thaw) and stored at $-30{ }^{\circ} \mathrm{C}$ under an atmosphere of argon. Storing under ambient conditions leads to decomposition of all products!

$N$-[2-(1H-Inden-1-yl)ethyl]aniline (3a). Aniline (6a, $419 \mathrm{mg}, 4.5 \mathrm{mmol})$ was used as substrate. The reaction time was 30 minutes. The crude product was purified by flash chromatography $\left(\mathrm{SiO}_{2}, \mathrm{PE} / \mathrm{MTBE} 9: 1 \rightarrow 1: 1\right)$ to give product 3a $(607 \mathrm{mg}, 2.6 \mathrm{mmol}, 86 \%)$ as a pale yellow oil. $\mathrm{R}_{\mathrm{f}}$ $0.27\left(\mathrm{SiO}_{2}, \mathrm{PE} / \mathrm{MTBE}\right.$ 9:1); IR (ATR, $v_{\max }, \mathrm{cm}^{-1}$ ): 3409 (w) (NH), 3052 (w), 3020 (w), 2925 (w), 2857 (w), 1601 (vs), 1504 (vs), 1319 (s), 1259 (m); ${ }^{1} \mathrm{H}$ NMR (499.9 MHz, $\mathrm{CDCl}_{3}$ ): $\delta_{\mathrm{H}}$ 1.92-2.02 $\left(1 \mathrm{H}, \mathrm{m}, \mathrm{CH}_{2}\right), 2.23-2.32\left(1 \mathrm{H}, \mathrm{m}, \mathrm{CH}_{2}\right), 3.11-3.26\left(2 \mathrm{H}, \mathrm{m}, \mathrm{CH}_{2}\right), 3.61(1 \mathrm{H}$, br. s, $\mathrm{NH}), 3.65(1 \mathrm{H}, \mathrm{t}$, $\left.{ }^{3} J_{\mathrm{H}, \mathrm{H}} 6.5 \mathrm{~Hz}, \mathrm{CH}\right), 6.56-6.62(3 \mathrm{H}, \mathrm{m}, 3 \mathrm{CH}), 6.73\left(1 \mathrm{H}, \mathrm{t},{ }^{3} J_{\mathrm{H}, \mathrm{H}} 7.3 \mathrm{~Hz}, \mathrm{CH}\right), 6.89\left(1 \mathrm{H}, \mathrm{d},{ }^{3} J_{\mathrm{H}, \mathrm{H}} 5.3\right.$ $\mathrm{Hz}, \mathrm{CH}), 7.20\left(2 \mathrm{H}, \mathrm{t},{ }^{3} J_{\mathrm{H}, \mathrm{H}} 7.8 \mathrm{~Hz}, 2 \mathrm{CH}\right), 7.24\left(1 \mathrm{H}, \mathrm{t},{ }^{3} J_{\mathrm{H}, \mathrm{H}} 7.4 \mathrm{~Hz}, \mathrm{CH}\right), 7.31\left(1 \mathrm{H}, \mathrm{t},{ }^{3} J_{\mathrm{H}, \mathrm{H}} 7.4\right.$ $\mathrm{Hz}, \mathrm{CH}), 7.41\left(1 \mathrm{H}, \mathrm{d},{ }^{3} J_{\mathrm{H}, \mathrm{H}} 7.4 \mathrm{~Hz}, \mathrm{CH}\right), 7.46\left(1 \mathrm{H}, \mathrm{d},{ }^{3} J_{\mathrm{H}, \mathrm{H}} 7.4 \mathrm{~Hz}, \mathrm{CH}\right) ;{ }^{13} \mathrm{C} \mathrm{NMR}(125.7 \mathrm{MHz}$, $\left.\mathrm{CDCl}_{3}\right): \delta_{\mathrm{C}} 30.9\left(\mathrm{CH}_{2}\right), 41.8\left(\mathrm{CH}_{2}\right), 48.4(\mathrm{CH}), 112.8(\mathrm{CH}), 117.3(\mathrm{CH}), 121.2(\mathrm{CH}), 122.8(\mathrm{CH})$, $124.9(\mathrm{CH}), 126.7(\mathrm{CH}), 129.2(\mathrm{CH}), 131.5(\mathrm{CH}), 138.4(\mathrm{CH}), 144.2(\mathrm{C}), 147.0(\mathrm{C}), 148.0(\mathrm{C})$; HRMS (ESI+) calcd. for $\left[\mathrm{C}_{17} \mathrm{H}_{17} \mathrm{~N}+\mathrm{H}\right]^{+}: 236.1439$. Found: 236.1441.

$N$-[2-(1H-Inden-1-yl)ethyl]-4-(trifluoromethyl)aniline (3b). 4-(Trifluoromethyl)aniline (6b, $725 \mathrm{mg}, 4.5 \mathrm{mmol}$ ) was used as substrate. The reaction time was 15 minutes. The crude product was purified by flash chromatography $\left(\mathrm{SiO}_{2}\right.$, PE/MTBE $\left.9: 1 \rightarrow 1: 2\right)$ to give product $\mathbf{3 b}(827 \mathrm{mg}$, $2.7 \mathrm{mmol}, 91 \%)$ as a colorless oil. $\mathrm{R}_{\mathrm{f}} 0.24\left(\mathrm{SiO}_{2}, \mathrm{PE} / \mathrm{MTBE} 4: 1\right)$; IR (ATR, $\left.v_{\max }, \mathrm{cm}^{-1}\right): 3418$ (w) (NH), $3067(\mathrm{w}), 2930(\mathrm{w}), 2863$ (w), 1617 (vs), 1535 (s), 1320 (vs), 1103 (vs), 1063 (vs); ${ }^{1} \mathrm{H}$ NMR (499.9 MHz, $\left.\mathrm{CDCl}_{3}\right): \delta_{\mathrm{H}} 1.98-2.08\left(1 \mathrm{H}, \mathrm{m}, \mathrm{CH}_{2}\right), 2.24-2.34\left(1 \mathrm{H}, \mathrm{m}, \mathrm{CH}_{2}\right), 3.09-3.17(1 \mathrm{H}$, m, $\left.\mathrm{CH}_{2}\right), 3.17-3.25\left(1 \mathrm{H}, \mathrm{m}, \mathrm{CH}_{2}\right), 3.66\left(1 \mathrm{H}, \mathrm{t},{ }^{3} \mathrm{~J}_{\mathrm{H}, \mathrm{H}} 5.9 \mathrm{~Hz}, \mathrm{CH}\right), 3.84(1 \mathrm{H}$, br. s, NH), $6.52(2 \mathrm{H}$, $\left.\mathrm{d},{ }^{3} J_{\mathrm{H}, \mathrm{H}} 8.4 \mathrm{~Hz}, 2 \mathrm{CH}\right), 6.59\left(1 \mathrm{H}, \mathrm{d},{ }^{3} J_{\mathrm{H}, \mathrm{H}} 5.2 \mathrm{~Hz}, \mathrm{CH}\right), 6.92\left(1 \mathrm{H}, \mathrm{d},{ }^{3} J_{\mathrm{H}, \mathrm{H}} 5.0 \mathrm{~Hz}, \mathrm{CH}\right), 7.28(1 \mathrm{H}, \mathrm{t}$, $\left.{ }^{3} J_{\mathrm{H}, \mathrm{H}} 7.2 \mathrm{~Hz}, \mathrm{CH}\right), 7.35\left(1 \mathrm{H}, \mathrm{t},{ }^{3} J_{\mathrm{H}, \mathrm{H}} 7.2 \mathrm{~Hz}, \mathrm{CH}\right), 7.40-7.49(4 \mathrm{H}, \mathrm{m}, 4 \mathrm{CH}) ;{ }^{13} \mathrm{C}$ NMR $(125.7$ $\left.\mathrm{MHz}, \mathrm{CDCl}_{3}\right): \delta_{\mathrm{C}} 30.4\left(\mathrm{CH}_{2}\right), 41.1\left(\mathrm{CH}_{2}\right), 48.2(\mathrm{CH}), 111.7(\mathrm{CH}), 118.6\left(\mathrm{q},{ }^{2} J_{\mathrm{C}, \mathrm{F}} 32.5 \mathrm{~Hz}, \mathrm{C}\right)$, $121.4(\mathrm{CH}), 122.7(\mathrm{CH}), 125.0(\mathrm{CH}), 125.1$ (q, $\left.{ }^{1} J_{\mathrm{C}, \mathrm{F}} 270.3 \mathrm{~Hz}, \mathrm{CF}_{3}\right), 126.5\left(\mathrm{q},{ }^{3} J_{\mathrm{C}, \mathrm{F}} 3.6 \mathrm{~Hz}, \mathrm{CH}\right)$, 
$126.8(\mathrm{CH}), 131.7(\mathrm{CH}), 138.1(\mathrm{CH}), 144.2(\mathrm{C}), 146.8(\mathrm{C}), 150.4(\mathrm{C}) ;{ }^{19} \mathrm{~F}$ NMR (470.3 MHz, $\left.\mathrm{CDCl}_{3}\right): \delta_{\mathrm{F}}-60.8\left(3 \mathrm{~F}, \mathrm{~s}, \mathrm{CF}_{3}\right)$; HRMS (ESI+) calcd. for $\left[\mathrm{C}_{18} \mathrm{H}_{16} \mathrm{~F}_{3} \mathrm{~N}+\mathrm{H}\right]^{+}:$304.1313. Found: 304.1313.

$N$-[2-(1H-Inden-1-yl)ethyl]-4-methoxyaniline (3c). 4-Methoxyaniline (6c, $554 \mathrm{mg}, 4.5 \mathrm{mmol})$ was used as substrate. The reaction time was two hours. The crude product was purified by flash chromatography $\left(\mathrm{SiO}_{2}\right.$, PE/MTBE 9:1 $\left.\rightarrow 1: 2\right)$ to give product 3c $(695 \mathrm{mg}, 2.6 \mathrm{mmol}, 87 \%)$ as an orange oil. $\mathrm{R}_{\mathrm{f}} 0.20\left(\mathrm{SiO}_{2}, \mathrm{PE} / \mathrm{MTBE} 4: 1\right)$; IR (ATR, $\left.v_{\max }, \mathrm{cm}^{-1}\right)$ : $3392(\mathrm{w})(\mathrm{NH}), 3059(\mathrm{w}), 2930$ (w), 2855 (w), 2831 (w), 1509 (vs), 1232 (vs), 1035 (s); ${ }^{1} \mathrm{H}$ NMR (499.9 $\mathrm{MHz}, \mathrm{CDCl}_{3}$ ): $\delta_{\mathrm{H}}$ 1.89$1.99\left(1 \mathrm{H}, \mathrm{m}, \mathrm{CH}_{2}\right), 2.20-2.29\left(1 \mathrm{H}, \mathrm{m}, \mathrm{CH}_{2}\right), 3.07-3.21\left(2 \mathrm{H}, \mathrm{m}, \mathrm{CH}_{2}\right), 3.24(1 \mathrm{H}$, br. s, $\mathrm{NH}), 3.63$ $\left(1 \mathrm{H}, \mathrm{t},{ }^{3} \mathrm{~J}_{\mathrm{H}, \mathrm{H}} 6.8 \mathrm{~Hz}, \mathrm{CH}\right), 3.76\left(3 \mathrm{H}, \mathrm{s}, \mathrm{CH}_{3}\right), 6.52-6.57(2 \mathrm{H}, \mathrm{m}, 2 \mathrm{CH}), 6.59\left(1 \mathrm{H}, \mathrm{d},{ }^{3} J_{\mathrm{H}, \mathrm{H}} 5.5 \mathrm{~Hz}\right.$, $\mathrm{CH}), 6.77-6.81(2 \mathrm{H}, \mathrm{m}, 2 \mathrm{CH}), 6.87\left(1 \mathrm{H}, \mathrm{d},{ }^{3} J_{\mathrm{H}, \mathrm{H}} 5.5 \mathrm{~Hz}, \mathrm{CH}\right), 7.23\left(1 \mathrm{H}, \mathrm{t},{ }^{3} J_{\mathrm{H}, \mathrm{H}} 7.4 \mathrm{~Hz}, \mathrm{CH}\right)$, $7.30\left(1 \mathrm{H}, \mathrm{t},{ }^{3} J_{\mathrm{H}, \mathrm{H}} 7.4 \mathrm{~Hz}, \mathrm{CH}\right), 7.40\left(1 \mathrm{H}, \mathrm{d},{ }^{3} J_{\mathrm{H}, \mathrm{H}} 7.4 \mathrm{~Hz}, \mathrm{CH}\right), 7.44\left(1 \mathrm{H}, \mathrm{d},{ }^{3} J_{\mathrm{H}, \mathrm{H}} 7.4 \mathrm{~Hz}, \mathrm{CH}\right) ;{ }^{13} \mathrm{C}$ NMR $\left(125.7 \mathrm{MHz}, \mathrm{CDCl}_{3}\right): \delta_{\mathrm{C}} 31.0\left(\mathrm{CH}_{2}\right), 42.9\left(\mathrm{CH}_{2}\right), 48.4(\mathrm{CH}), 55.8\left(\mathrm{CH}_{3}\right), 114.2(\mathrm{CH})$, $114.9(\mathrm{CH}), 121.2(\mathrm{CH}), 122.8(\mathrm{CH}), 124.9(\mathrm{CH}), 126.6(\mathrm{CH}), 131.4(\mathrm{CH}), 138.5(\mathrm{CH}), 142.3$ (C), 144.2 (C), 147.1 (C), 152.2 (C); HRMS (ESI+) calcd. for $\left[\mathrm{C}_{18} \mathrm{H}_{19} \mathrm{NO}+\mathrm{H}\right]^{+}$: 266.1545. Found: 266.1537.

$N$-[2-(1H-Inden-3-yl)ethyl]pyridin-2-amine (4d). 2-Aminopyridine (6d, $424 \mathrm{mg}, 4.5 \mathrm{mmol})$ was used as substrate. The reaction time was 24 hours. The crude product was purified by flash chromatography $\left(\mathrm{SiO}_{2}\right.$, PE/MTBE 9:1 $\rightarrow$ MTBE) to give product 4d (423 mg, $\left.1.8 \mathrm{mmol}, 60 \%\right)$ as a pale yellow solid. $\mathrm{R}_{\mathrm{f}} 0.28\left(\mathrm{SiO}_{2}\right.$, PE/MTBE 1:2); mp 96-97 ${ }^{\circ} \mathrm{C}$; IR (ATR, $\left.v_{\max }, \mathrm{cm}^{-1}\right): 3226(\mathrm{~m})$ (NH), 3090 (w), 3017 (w), 2948 (w), 2860 (w), 1604 (vs), 1575 (vs), 1452 (vs), 1440 (vs); ${ }^{1} \mathrm{H}$ NMR (499.9 MHz, $\left.\mathrm{CDCl}_{3}\right): \delta_{\mathrm{H}} 2.91\left(2 \mathrm{H}, \mathrm{t},{ }^{3} \mathrm{~J}_{\mathrm{H}, \mathrm{H}} 6.8 \mathrm{~Hz}, \mathrm{CH}_{2}\right), 3.37\left(2 \mathrm{H}, \mathrm{s}, \mathrm{CH}_{2}\right), 3.65(2 \mathrm{H}, \mathrm{q}$, $\left.{ }^{3} J_{\mathrm{H}, \mathrm{H}} 6.5 \mathrm{~Hz}, \mathrm{CH}_{2}\right), 4.59\left(1 \mathrm{H}\right.$, br. s, NH), $6.33(1 \mathrm{H}, \mathrm{s}, \mathrm{CH}), 6.38\left(1 \mathrm{H}, \mathrm{d},{ }^{3} J_{\mathrm{H}, \mathrm{H}} 8.4 \mathrm{~Hz}, \mathrm{CH}\right), 6.54-$ $6.60(1 \mathrm{H}, \mathrm{m}, \mathrm{CH}), 7.23\left(1 \mathrm{H}, \mathrm{t},{ }^{3} J_{\mathrm{H}, \mathrm{H}} 7.4 \mathrm{~Hz}, \mathrm{CH}\right), 7.31\left(1 \mathrm{H}, \mathrm{t},{ }^{3} J_{\mathrm{H}, \mathrm{H}} 7.4 \mathrm{~Hz}, \mathrm{CH}\right), 7.38-7.44(2 \mathrm{H}$, $\mathrm{m}, 2 \mathrm{CH}), 7.48\left(1 \mathrm{H}, \mathrm{d},{ }^{3} J_{\mathrm{H}, \mathrm{H}} 7.3 \mathrm{~Hz}, \mathrm{CH}\right), 8.11\left(1 \mathrm{H}, \mathrm{d},{ }^{3} J_{\mathrm{H}, \mathrm{H}} 4.2 \mathrm{~Hz}, \mathrm{CH}\right) ;{ }^{13} \mathrm{C} \mathrm{NMR}(125.7 \mathrm{MHz}$, $\left.\mathrm{CDCl}_{3}\right): \delta_{\mathrm{C}} 27.8\left(\mathrm{CH}_{2}\right), 37.9\left(\mathrm{CH}_{2}\right), 40.5\left(\mathrm{CH}_{2}\right), 106.8(\mathrm{CH}), 112.8(\mathrm{CH}), 118.9(\mathrm{CH}), 123.8$ $(\mathrm{CH}), 124.8(\mathrm{CH}), 126.1(\mathrm{CH}), 129.5(\mathrm{CH}), 137.3(\mathrm{CH}), 141.5(\mathrm{C}), 144.4(\mathrm{C}), 144.9(\mathrm{C}), 148.3$ $(\mathrm{CH}), 158.7(\mathrm{C})$; HRMS (ESI+) calcd. for $\left[\mathrm{C}_{16} \mathrm{H}_{16} \mathrm{~N}_{2}+\mathrm{H}\right]^{+}$: 237.1392. Found: 237.1395.

[2-(1H-Inden-3-yl)ethyl](propan-2-yl)amine (4e). Isopropylamine (6e, $266 \mathrm{mg}, 4.5 \mathrm{mmol}$ ) was used as substrate. The reaction time was two hours. The crude product was purified by flash chromatography $\left(\mathrm{SiO}_{2}, \mathrm{PE} / \mathrm{MTBE} 9: 1 \rightarrow \mathrm{MTBE}\right)$ to give product $4 \mathbf{e}(305 \mathrm{mg}, 1.5 \mathrm{mmol}, 51 \%)$ as a pale yellow oil. $\mathrm{R}_{\mathrm{f}} 0.16\left(\mathrm{SiO}_{2}, \mathrm{MTBE} / \mathrm{MeOH}\right.$ 9:1); IR (ATR, $\left.v_{\max }, \mathrm{cm}^{-1}\right)$ : 3066 (w), $3020(\mathrm{w})$, 2964 (m), 2899 (w), 2831 (w), 1463 (s), 1172 (s); ${ }^{1} \mathrm{H}$ NMR (499.9 MHz, CDCl $)_{3}$ ): $\delta_{\mathrm{H}} 1.08$ (6H, d, $\left.{ }^{3} J_{\mathrm{H}, \mathrm{H}} 6.2 \mathrm{~Hz}, 2 \mathrm{CH}_{3}\right), 1.32\left(1 \mathrm{H}\right.$, br. s, NH), $2.78\left(2 \mathrm{H}, \mathrm{t},{ }^{3} J_{\mathrm{H}, \mathrm{H}} 7.2 \mathrm{~Hz}, \mathrm{CH}_{2}\right), 2.85\left(1 \mathrm{H}, \mathrm{hept},{ }^{3} J_{\mathrm{H}, \mathrm{H}}\right.$ $6.2 \mathrm{~Hz}, \mathrm{CH}), 2.96\left(2 \mathrm{H}, \mathrm{t},{ }^{3} \mathrm{~J}_{\mathrm{H}, \mathrm{H}} 7.2 \mathrm{~Hz}, \mathrm{CH}_{2}\right), 3.35\left(2 \mathrm{H}, \mathrm{s}, \mathrm{CH}_{2}\right), 6.28(1 \mathrm{H}, \mathrm{s}, \mathrm{CH}), 7.21(1 \mathrm{H}, \mathrm{t}$, $\left.{ }^{3} J_{\mathrm{H}, \mathrm{H}} 7.4 \mathrm{~Hz}, \mathrm{CH}\right), 7.30\left(1 \mathrm{H}, \mathrm{t},{ }^{3} J_{\mathrm{H}, \mathrm{H}} 7.4 \mathrm{~Hz}, \mathrm{CH}\right), 7.39\left(1 \mathrm{H}, \mathrm{d},{ }^{3} J_{\mathrm{H}, \mathrm{H}} 7.4 \mathrm{~Hz}, \mathrm{CH}\right), 7.47(1 \mathrm{H}, \mathrm{d}$, $\left.{ }^{3} J_{\mathrm{H}, \mathrm{H}} 7.4 \mathrm{~Hz}, \mathrm{CH}\right) ;{ }^{13} \mathrm{C} \mathrm{NMR}\left(125.7 \mathrm{MHz}, \mathrm{CDCl}_{3}\right): \delta_{\mathrm{C}} 23.0\left(\mathrm{CH}_{3}\right), 28.6\left(\mathrm{CH}_{2}\right), 37.8\left(\mathrm{CH}_{2}\right), 45.7$ $\left(\mathrm{CH}_{2}\right), 48.6(\mathrm{CH}), 118.9(\mathrm{CH}), 123.7(\mathrm{CH}), 124.6(\mathrm{CH}), 126.0(\mathrm{CH}), 128.8(\mathrm{CH}), 142.3(\mathrm{C})$, 144.4 (C), 145.2 (C); HRMS (ESI+) calcd. for $\left[\mathrm{C}_{14} \mathrm{H}_{19} \mathrm{~N}+\mathrm{Na}\right]^{+}:$224.1415. Found: 224.1418. 
[2-(1H-Inden-3-yl)ethyl](2-methylpropan-2-yl)amine (4f). tert-Butylamine (6f, 329 mg, 4.5 mmol) was used as substrate. The reaction time was two hours. The crude product was purified by flash chromatography ( $\left.\mathrm{SiO}_{2}, \mathrm{PE} / \mathrm{MTBE} 9: 1 \rightarrow \mathrm{MTBE}\right)$ to give product $\mathbf{4 f}(535 \mathrm{mg}, 2.5 \mathrm{mmol}$, $83 \%$ ) as a colorless oil. $\mathrm{R}_{\mathrm{f}} 0.15\left(\mathrm{SiO}_{2}, \mathrm{MTBE} / \mathrm{MeOH}\right.$ 9:1); IR (ATR, $\left.v_{\max }, \mathrm{cm}^{-1}\right): 3066(\mathrm{w}), 3041$ (w), 3018 (w), 2962 (m), 2903 (w), 1360 (m), 1231 (m); ${ }^{1} \mathrm{H}$ NMR (499.9 MHz, $\mathrm{CDCl}_{3}$ ): $\delta_{\mathrm{H}} 0.86$ $\left(1 \mathrm{H}\right.$, br. s, NH), $1.11\left(9 \mathrm{H}, \mathrm{s}, 3 \mathrm{CH}_{3}\right), 2.73-2.78\left(2 \mathrm{H}, \mathrm{m}, \mathrm{CH}_{2}\right), 2.93\left(2 \mathrm{H}, \mathrm{t},{ }^{3} J_{\mathrm{H}, \mathrm{H}} 7.3 \mathrm{~Hz}, \mathrm{CH}_{2}\right)$, 3.33-3.36 (2H, m, $\left.\mathrm{CH}_{2}\right), 6.26-6.30(1 \mathrm{H}, \mathrm{m}, \mathrm{CH}), 7.21\left(1 \mathrm{H}, \mathrm{td},{ }^{3} J_{\mathrm{H}, \mathrm{H}} 7.4 \mathrm{~Hz},{ }^{4} J_{\mathrm{H}, \mathrm{H}} 0.9 \mathrm{~Hz}, \mathrm{CH}\right)$, $7.30\left(1 \mathrm{H}, \mathrm{t},{ }^{3} J_{\mathrm{H}, \mathrm{H}} 7.4 \mathrm{~Hz}, \mathrm{CH}\right), 7.39\left(1 \mathrm{H}, \mathrm{d},{ }^{3} J_{\mathrm{H}, \mathrm{H}} 7.4 \mathrm{~Hz}, \mathrm{CH}\right), 7.47\left(1 \mathrm{H}, \mathrm{d},{ }^{3} J_{\mathrm{H}, \mathrm{H}} 7.4 \mathrm{~Hz}, \mathrm{CH}\right) ;{ }^{13} \mathrm{C}$ NMR (125.7 MHz, $\left.\mathrm{CDCl}_{3}\right): \delta_{\mathrm{C}} 29.1\left(\mathrm{CH}_{3}\right), 29.3\left(\mathrm{CH}_{2}\right), 37.8\left(\mathrm{CH}_{2}\right), 41.0\left(\mathrm{CH}_{2}\right), 50.3(\mathrm{C}), 119.0$ $(\mathrm{CH}), 123.7(\mathrm{CH}), 124.6(\mathrm{CH}), 126.0(\mathrm{CH}), 128.7(\mathrm{CH}), 142.4(\mathrm{C}), 144.4(\mathrm{C}), 145.2(\mathrm{C})$; HRMS (ESI+) calcd. for $\left[\mathrm{C}_{15} \mathrm{H}_{21} \mathrm{~N}+\mathrm{H}\right]^{+}: 216.1752$. Found: 216.1747.

[2-(1H-Inden-3-yl)ethyl]cyclohexylamine (4g). Cyclohexylamine (6g, $446 \mathrm{mg}, 4.5 \mathrm{mmol})$ was used as substrate. The reaction time was two hours. The crude product was purified by flash chromatography $\left(\mathrm{SiO}_{2}\right.$, $\left.\mathrm{PE} / \mathrm{MTBE} 9: 1 \rightarrow \mathrm{MTBE}\right)$ to give product $4 \mathrm{~g}(469 \mathrm{mg}, 1.9 \mathrm{mmol}, 65 \%)$ as a colorless oil. $\mathrm{R}_{\mathrm{f}} 0.20\left(\mathrm{SiO}_{2}, \mathrm{MTBE} / \mathrm{MeOH}\right.$ 9:1); IR (ATR, $\left.v_{\max }, \mathrm{cm}^{-1}\right): 3234(\mathrm{~m})(\mathrm{NH}), 3070$ (w), 3021 (w), 2929 (vs), 2853 (vs), 1462 (s), 1372 (s), 1121 (vs); ${ }^{1} \mathrm{H}$ NMR (499.9 MHz, $\left.\mathrm{CDCl}_{3}\right): \delta_{\mathrm{H}} 1.04-1.32\left(5 \mathrm{H}, \mathrm{m}, \mathrm{CH}_{2}\right), 1.46(1 \mathrm{H}$, br. s, $\mathrm{NH}), 1.58-1.65\left(1 \mathrm{H}, \mathrm{m}, \mathrm{CH}_{2}\right), 1.69-1.77$ $\left(2 \mathrm{H}, \mathrm{m}, \mathrm{CH}_{2}\right), 1.85-1.93\left(2 \mathrm{H}, \mathrm{m}, \mathrm{CH}_{2}\right), 2.47\left(1 \mathrm{H}, \mathrm{tt},{ }^{3} J_{\mathrm{H}, \mathrm{H}} 10.4 \mathrm{~Hz},{ }^{3} J_{\mathrm{H}, \mathrm{H}} 3.6 \mathrm{~Hz}, \mathrm{CH}\right), 2.78(2 \mathrm{H}, \mathrm{t}$, $\left.{ }^{3} J_{\mathrm{H}, \mathrm{H}} 7.2 \mathrm{~Hz}, \mathrm{CH}_{2}\right), 2.99\left(2 \mathrm{H}, \mathrm{t},{ }^{3} J_{\mathrm{H}, \mathrm{H}} 7.2 \mathrm{~Hz}, \mathrm{CH}_{2}\right), 3.34\left(2 \mathrm{H}, \mathrm{s}, \mathrm{CH}_{2}\right), 6.27(1 \mathrm{H}, \mathrm{s}, \mathrm{CH}), 7.21$ $\left(1 \mathrm{H}, \mathrm{t},{ }^{3} J_{\mathrm{H}, \mathrm{H}} 7.4 \mathrm{~Hz}, \mathrm{CH}\right), 7.30\left(1 \mathrm{H}, \mathrm{t},{ }^{3} J_{\mathrm{H}, \mathrm{H}} 7.4 \mathrm{~Hz}, \mathrm{CH}\right), 7.39\left(1 \mathrm{H}, \mathrm{d},{ }^{3} J_{\mathrm{H}, \mathrm{H}} 7.4 \mathrm{~Hz}, \mathrm{CH}\right), 7.46$ $\left(1 \mathrm{H}, \mathrm{d},{ }^{3} J_{\mathrm{H}, \mathrm{H}} 7.4 \mathrm{~Hz}, \mathrm{CH}\right) ;{ }^{13} \mathrm{C} \mathrm{NMR}\left(125.7 \mathrm{MHz}, \mathrm{CDCl}_{3}\right): \delta_{\mathrm{C}} 25.1\left(\mathrm{CH}_{2}\right), 26.2\left(\mathrm{CH}_{2}\right), 28.7$ $\left(\mathrm{CH}_{2}\right), 33.6\left(\mathrm{CH}_{2}\right), 37.8\left(\mathrm{CH}_{2}\right), 45.1\left(\mathrm{CH}_{2}\right), 56.8(\mathrm{CH}), 119.0(\mathrm{CH}), 123.7(\mathrm{CH}), 124.6(\mathrm{CH})$, $126.0(\mathrm{CH}), 128.8(\mathrm{CH}), 142.3(\mathrm{C}), 144.4(\mathrm{C}), 145.2$ (C); HRMS (ESI+) calcd. for $\left[\mathrm{C}_{17} \mathrm{H}_{23} \mathrm{~N}+\mathrm{H}\right]^{+}: 242.1909$. Found: 242.1903.

[2-(1H-Inden-1-yl)ethyl][(R)-1-phenylethyl]amine $(3 \mathrm{~h})$ and [2-(1H-inden-3-yl)ethyl][(R)-1phenylethyl]amine (4h). (R)-1-Phenylethylamine (6h, $545 \mathrm{mg}, 4.5 \mathrm{mmol})$ was used as substrate. The reaction time was two hours. The crude product was purified by flash chromatography $\left(\mathrm{SiO}_{2}, \mathrm{PE} / \mathrm{MTBE}\right.$ 9:1 $\rightarrow$ MTBE$)$ to give a mixture of the regioisomers $\mathbf{3 h}$ and $\mathbf{4 h}$ (633 $\mathrm{mg}, 2.4$ mmol, $80 \%, \mathbf{3 h} / \mathbf{4 h}$ 16:84) as a pale yellow oil. $\mathrm{R}_{\mathrm{f}} 0.32\left(\mathrm{SiO}_{2}, \mathrm{MTBE} / \mathrm{MeOH}\right.$ 19:1); IR (ATR, $v_{\max }, \mathrm{cm}^{-1}$, mixture of $\mathbf{3 h}$ and $\mathbf{4 h}$ ): 3061 (w), $3022(\mathrm{w}), 2960(\mathrm{w}), 2923(\mathrm{w}), 2885(\mathrm{w}), 2836(\mathrm{w})$, 1451 (m), $1124(\mathrm{~m}) ;{ }^{1} \mathrm{H}$ NMR (499.9 MHz, $\mathrm{CDCl}_{3}$, mixture of $\mathbf{3 h}$ and $\left.\mathbf{4 h}\right) \mathbf{4 h}: \delta_{\mathrm{H}} 1.34$ (1H, br. s, $\mathrm{NH}), 1.36\left(3 \mathrm{H}, \mathrm{d},{ }^{3} \mathrm{~J}_{\mathrm{H}, \mathrm{H}} 6.6 \mathrm{~Hz}, \mathrm{CH}_{3}\right), 2.71-2.90\left(4 \mathrm{H}, \mathrm{m}, 2 \mathrm{CH}_{2}\right), 3.30-3.35\left(2 \mathrm{H}, \mathrm{m}, \mathrm{CH}_{2}\right), 3.81$ $\left(1 \mathrm{H}, \mathrm{q},{ }^{3} \mathrm{~J}_{\mathrm{H}, \mathrm{H}} 6.6 \mathrm{~Hz}, \mathrm{CH}\right), 6.20-6.24(1 \mathrm{H}, \mathrm{m}, \mathrm{CH}), 7.13-7.37(8 \mathrm{H}, \mathrm{m}, 8 \mathrm{CH}), 7.43-7.47(1 \mathrm{H}, \mathrm{m}$, $\mathrm{CH})$; important signals of minor isomer $3 \mathrm{~h}: \delta_{\mathrm{H}} 1.30-1.35\left(3 \mathrm{H}, \mathrm{m}, \mathrm{CH}_{3}\right), 1.61-1.74\left(1 \mathrm{H}, \mathrm{m}, \mathrm{CH}_{2}\right)$, 2.01-2.05 (1H, m, $\left.\mathrm{CH}_{2}\right), 2.53-2.70\left(2 \mathrm{H}, \mathrm{m}, \mathrm{CH}_{2}\right), 3.50-3.58(1 \mathrm{H}, \mathrm{m}, \mathrm{CH}), 3.75\left(1 \mathrm{H}, \mathrm{q},{ }^{3} J_{\mathrm{H}, \mathrm{H}} 6.6\right.$ $\mathrm{Hz}, \mathrm{CH}), 6.44-6.52(1 \mathrm{H}, \mathrm{m}, \mathrm{CH}), 6.76-6.80(1 \mathrm{H}, \mathrm{m}, \mathrm{CH}) ;{ }^{13} \mathrm{C} \mathrm{NMR}\left(125.7 \mathrm{MHz}, \mathrm{CDCl}_{3}\right.$, mixture of $3 \mathbf{h}$ and $4 \mathbf{h}) 4 \mathbf{h}: \delta_{\mathrm{C}} 24.4\left(\mathrm{CH}_{3}\right), 28.4\left(\mathrm{CH}_{2}\right), 37.8\left(\mathrm{CH}_{2}\right), 45.9\left(\mathrm{CH}_{2}\right), 58.2(\mathrm{CH}), 119.0(\mathrm{CH})$, $123.7(\mathrm{CH}), 124.6(\mathrm{CH}), 126.0(\mathrm{CH}), 126.5(\mathrm{CH}), 126.8(\mathrm{CH}), 128.4(\mathrm{CH}), 128.8(\mathrm{CH}), 142.2$ (C), $144.4(\mathrm{C}), 145.2(\mathrm{C}), 145.7(\mathrm{C})$; HRMS (ESI+) calcd. for $\left[\mathrm{C}_{19} \mathrm{H}_{21} \mathrm{~N}+\mathrm{H}\right]^{+}:$264.1752. Found: 264.1757. 
Complex $\left[\left\{\left(\boldsymbol{\eta}^{5}-\mathbf{C}_{9} \mathbf{H}_{6}\right) \mathbf{C}_{2} \mathbf{H}_{4}\left(\boldsymbol{\eta}^{1}-\mathbf{N P h}\right)\right\} \mathbf{T i C l}_{2}\right]$ (16). A flame-dried $100 \mathrm{~mL}$ round-bottom Schlenkflask equipped with a Teflon ${ }^{\circledR}$-coated oval stirring bar $(2 \mathrm{~cm})$ and a septum was charged with amine $3 \mathrm{a}(1.34 \mathrm{~g}, 5.7 \mathrm{mmol})$ and diethyl ether $(50 \mathrm{~mL})$ and was cooled to $-78^{\circ} \mathrm{C}$. A solution of $n$-butyllithium $\left(3.14 \mathrm{~g}, c=2.5 \mathrm{~mol} \cdot \mathrm{L}^{-1}\right.$ in hexanes, $\left.11.4 \mathrm{mmol}\right)$ was added dropwise at $-78{ }^{\circ} \mathrm{C}$ and subsequently, the resulting mixture was stirred at $25{ }^{\circ} \mathrm{C}$ for three hours to form a white suspension of the dilithium salt 15. A flame-dried $250 \mathrm{~mL}$ round-bottom Schlenk-flask equipped with a Teflon ${ }^{\circledR}$-coated oval stirring bar $(2.5 \mathrm{~cm})$ and a septum was charged with diethyl ether (50 $\mathrm{mL}$ ) and cooled to $-78{ }^{\circ} \mathrm{C}$. Titanium tetrachloride $(1.08 \mathrm{~g}, 5.7 \mathrm{mmol})$ was added via syringe and the resulting mixture was stirred for 15 minutes at $-78{ }^{\circ} \mathrm{C}$ to form a yellow suspension. Then the suspension of dilithium salt 15 was added via Teflon ${ }^{\circledR}$-cannula and the resulting mixture was stirred at $25^{\circ} \mathrm{C}$ for two hours. The solvent was removed under reduced pressure, the residue was suspended in toluene $(50 \mathrm{~mL})$, filtered through $\mathrm{Na}_{2} \mathrm{SO}_{4}$ and the residue was washed with toluene $(20 \mathrm{~mL})$. The combined filtrates were concentrated under vacuum to a volume of approximately $30 \mathrm{~mL}$ and stored at $-30{ }^{\circ} \mathrm{C}$ overnight to form red-brown crystals. The excess solvent was removed via syringe and the residue was dried under vacuum to give titanium complex 16 (668 $\mathrm{mg}, 1.9 \mathrm{mmol}, 33 \%)$ as a red-brown solid. $\mathrm{mp} 121-122{ }^{\circ} \mathrm{C}\left(\mathrm{dec}\right.$.); IR (ATR, $\left.v_{\max }, \mathrm{cm}^{-1}\right): 3098$ (w), $3053(\mathrm{w}), 2934$ (w), 2907 (w), 2853 (w), 1587 (m), 1478 (m), 1221 (m), 1200 (m), 1058 $(\mathrm{m}), 1042(\mathrm{~m}), 1024(\mathrm{~m}) ;{ }^{1} \mathrm{H}$ NMR $\left(499.9 \mathrm{MHz}\right.$, benzene-d $\mathrm{d}_{6}$, ferrocene): $\delta_{\mathrm{H}} 2.66-2.73(1 \mathrm{H}, \mathrm{m}$, $\left.\mathrm{CH}_{2}\right), 2.92-2.99\left(1 \mathrm{H}, \mathrm{m}, \mathrm{CH}_{2}\right), 4.18-4.24\left(1 \mathrm{H}, \mathrm{m}, \mathrm{CH}_{2}\right), 4.51-4.59\left(1 \mathrm{H}, \mathrm{m}, \mathrm{CH}_{2}\right), 6.25(1 \mathrm{H}, \mathrm{d}$, $\left.{ }^{3} J_{\mathrm{H}, \mathrm{H}} 3.3 \mathrm{~Hz}, \mathrm{CH}\right), 6.38\left(1 \mathrm{H}, \mathrm{d},{ }^{3} J_{\mathrm{H}, \mathrm{H}} 3.3 \mathrm{~Hz}, \mathrm{CH}\right), 6.83-6.88(1 \mathrm{H}, \mathrm{m}, \mathrm{CH}), 6.94-6.99(2 \mathrm{H}, \mathrm{m}$, $2 \mathrm{CH}), 7.10-7.15(2 \mathrm{H}, \mathrm{m}, 2 \mathrm{CH}), 7.17-7.22(1 \mathrm{H}, \mathrm{m}, \mathrm{CH}), 7.30-7.35(1 \mathrm{H}, \mathrm{m}, \mathrm{CH}), 7.37-7.42(2 \mathrm{H}$, $\mathrm{m}, 2 \mathrm{CH}) ;{ }^{13} \mathrm{C}$ NMR $\left(125.7 \mathrm{MHz}\right.$, benzene-d $\left.{ }_{6}\right): \delta_{\mathrm{C}} 27.4\left(\mathrm{CH}_{2}\right), 77.6\left(\mathrm{CH}_{2}\right), 107.5(\mathrm{CH}), 120.7$ $(\mathrm{CH}), 122.5(\mathrm{CH}), 123.1(\mathrm{CH}), 126.4(\mathrm{CH}), 127.0(\mathrm{CH}), 127.7(\mathrm{C}), 128.3(\mathrm{CH}), 128.3(\mathrm{C}), 128.4$ $(\mathrm{CH}), 129.4(\mathrm{CH}), 135.4(\mathrm{C}), 153.4(\mathrm{C})$; MS (LIFDI), $\mathrm{m} / z(\%)=355\left(\mathrm{C}_{17} \mathrm{H}_{15}{ }^{37} \mathrm{Cl}_{2} \mathrm{NTi}, 11\right), 353$ $\left(\mathrm{C}_{17} \mathrm{H}_{15}{ }^{35} \mathrm{Cl}^{37} \mathrm{ClNTi}, 68\right), 351\left(\mathrm{C}_{17} \mathrm{H}_{15}{ }^{35} \mathrm{Cl}_{2} \mathrm{NTi}, 100\right)$. Red crystals suitable for $\mathrm{X}$-ray singlecrystal analysis were obtained from a solution of complex $16(38 \mathrm{mg}, 0.1 \mathrm{mmol})$ in benzene- $\mathrm{d}_{6}$ $(0.6 \mathrm{~mL})$ which was stored in a sealed NMR tube at $25^{\circ} \mathrm{C}$ for three hours. ${ }^{19}$

\section{Acknowledgements}

We thank the Deutsche Forschungsgemeinschaft for financial support of our research. We further thank Professor Jürgen Martens for providing the mercury lamp for the photochemical reaction and Astrid Markgraf for recording the mass spectra. 


\section{Supplementary material}

The traces of all NMR spectra reported in this paper, along with the IR spectra of the novel compounds and the X-ray data of compounds $\mathbf{4 h} \cdot \mathbf{H C l}$ and $\mathbf{1 6}$ are accessible as Supplementary Data through the link to be found in the Contents page of the Journal.

\section{References}

1. Roesky, P. W. Angew. Chem. Int. Ed. 2009, 48, 4892-4894; Angew. Chem. 2009, 121, 49884991 , for a review on the hydroaminoalkylation of alkenes. http://dx.doi.org/10.1002/ange.200900735

2. Müller, C; Saak, W.; Doye, S. Eur. J. Org. Chem. 2008, 2731-2739. http://dx.doi.org/10.1002/ejoc.200701146

3. Kubiak, R.; Prochnow, I.; Doye, S. Angew. Chem. Int. Ed. 2009, 48, 1153-1156; Angew. Chem. 2009, 121, 1173-1176. http://dx.doi.org/10.1002/ange.200805169

4. Prochnow, I.; Kubiak, R.; Frey, O. N.; Beckhaus, R.; Doye, S. ChemCatChem 2009, 1, 162172. http://dx.doi.org/10.1002/cctc.200900092

5. Kubiak, R.; Prochnow, I.; Doye, S. Angew. Chem. Int. Ed. 2010, 49, 2626-2629; Angew. Chem. 2010, 122, 2683-2686. http://dx.doi.org/10.1002/ange.200906557

6. Prochnow, I.; Zark, P.; Müller, T.; Doye, S. Angew. Chem. Int. Ed. 2011, 50, 6401-6405; Angew. Chem. 2011, 123, 6525-6529. http://dx.doi.org/10.1002/ange.201101239

7. Jaspers, D.; Saak, W.; Doye, S. Synlett 2012, 23, 2098-2102. http://dx.doi.org/10.1055/s-0031-1290436

8. Dörfler, J.; Doye, S. Angew. Chem. Int. Ed. 2013, 52, 1806-1809; Angew. Chem. 2013, 125, 1851-1854. http://dx.doi.org/10.1002/ange.201206027

9. Preuss, T.; Saak, W.; Doye, S. Chem. Eur. J. 2013, 19, 3833-3837. http://dx.doi.org/10.1002/chem.201203693

10. Dörfler, J.; Preuss, T.; Schischko, A.; Schmidtmann, M.; Doye, S. Angew. Chem. Int. Ed. 2014, 53, 7918-7922; Angew. Chem. 2014, 126, 8052-8056. http://dx.doi.org/10.1002/ange.201403203

11. Chong, E.; Schafer, L. L. Org. Lett. 2013, 15, 6002-6005. http://dx.doi.org/10.1021/ol402890m

12. Ross, J. H.; Preuss, T.; Brahms, C.; Doye, S. Z. Anorg. Allg. Chem. 2014, 640, 118-121. http://dx.doi.org/10.1002/zaac.201300433 
13. Johnson, J. S.; Bergman, R. G. J. Am. Chem. Soc. 2001, 123, 2923-2924. http://dx.doi.org/10.1021/ja005685h

14. Braunschweig, H.; Breitling F. M. Coord. Chem. Rev. 2006, 250, 2691-2720, for a review on constrained geometry catalysts.

http://dx.doi.org/10.1016/j.ccr.2005.10.022

15. Ipaktschi, J. Chem. Ber. 1972, 105, 1840-1853.

http://dx.doi.org/10.1002/cber.19721050607

16. Coe, J. W.; Wirtz, M. C.; Bashore, C. G.; Candler, J. Org. Lett. 2004, 6, 1589-1592. http://dx.doi.org/10.1021/ol0496551

17. Sun, J.; Dong, Y.; Cao, L.; Wang, X.; Wang, S.; Hu, Y. J. Org. Chem. 2004, 69, 8932-8934. http://dx.doi.org/10.1021/jo0486239

18. Kim, S.; Oh, C. H.; Ko, J. S.; Ahn, K. H.; Kim, Y. J. J. Org. Chem. 1985, 50, 1927-1932. http://dx.doi.org/10.1021/jo00211a028

19. CCDC 1013015 (16) contains the supplementary crystallographic data for this paper. These data can be obtained free of charge from The Cambridge Crystallographic Data Centre via www.ccdc.cam.ac.uk/data_request/cif.

20. Herrmann, W. A.; Morawietz, M. J. A.; Priermeier, T. Angew. Chem. Int. Ed. Engl. 1994, 33, 1946-1949; Angew. Chem. 1994, 106, 2025-2028.

http://dx.doi.org/10.1002/ange.19941061911

21. Herrmann, W. A.; Baratta, W. J. Organomet. Chem. 1996, 506, 357-361. http://dx.doi.org/10.1016/0022-328X(95)05929-J

22. Hou, Z.; Koizumi, T.-a.; Nishiura, M.; Wakatsuki, Y. Organometallics 2001, 20, 3323-3328. http://dx.doi.org/10.1021/om010261x

23. Nishiura, M.; Hou, Z.; Wakatsuki, Y.; Yamaki, T.; Miyamoto, T. J. Am. Chem. Soc. 2003, 125, 1184-1185.

http://dx.doi.org/10.1021/ja027595d

24. Wilt, J. W.; Chenier, P. J. J. Org. Chem. 1970, 35, 1571-1576.

http://dx.doi.org/10.1021/jo00830a066

25. Bartlett, P. D.; Giddings, W. P. J. Am. Chem. Soc. 1960, 82, 1240-1246.

http://dx.doi.org/10.1021/ja01490a051 